\title{
Da Palavra à Imagem: sobre o programa decorativo de Affonso Taunay para o Museu Paulista
}

\author{
Claudia Valladão de Mattos
}

Instituto de Artes da Unicamp

A decoração interna do Museu Paulista já foi objeto de vários estudos e pesquisas ${ }^{1}$, porém em geral esses não se aprofundam na relação do programa decorativo elaborado por Taunay com a História da Arte, centrando-se prioritariamente na relação da decoração com o contexto político-ideológico dentro do qual ela nasceu. A posição central que o bandeirantismo paulista ocupa na decoração tem sido o principal alvo das análises realizadas até hoje. Maria José Elias ressalta, neste sentido - com razão - a estreita relação existente entre o fortalecimento das oligarquias paulistas, assim como a projeção de São Paulo no cenário nacional, e a execução do programa decorativo de Taunay para o Museu:

Em 1916, dá-se um verdadeiro terremoto mudancista no Museu Paulista: cai o diretorcientista e com ele se vai o projeto até então hegemônico de um instituto de ciências naturais. Em seu lugar irá se entronizar um projeto explicitamente ideológico, voltado mais para a relação memória e poder e menos para o par dialético ciência e poder. Esta guinada nos rumos do Museu Paulista terá como marco referencial as Comemorações do Centenário da Independência Nacional em 1922", escreve Elias, e mais adiante: "De sua sólida base local, o PRP tinha, pois, plenas condições de traçar e implementar ambiciosos planos que visavam à reconquista da hegemonia nacional. $E$, nesse início de século XX, a elite paulista já percebia que, ao lado dos tradicionais instrumentos de luta pela supremacia (conchavos políticos, saber técnico-científico, economia dinamizada, etc.), surgia agora uma nova arma: a cultura. $^{2}$

No mesmo sentido escreveu Nicolau Sevcenko a respeito do Museu de Taunay:

Essa elite (paulista) pretendeu fazer do símbolo da Independência, do fato de a Independência ter sido proclamada em território paulista, uma espécie de revelação, um fato representativo do sentido fundamental que São Paulo teria no contexto da Federação, como sendo aquele Estado que, desde o início de sua história continha já
1. Cf., entre outros, Ulpiano T. Bezera de Meneses, "O Salão Nobre do Museu Paulista e oTeatro da História." In: Às MARGENS do Ipiranga: 1800-1990. São Paulo: Bradesco/Museu Paulista, 1990.p.20-21.Catálogo de exposição. Miyoko Makino. "A Ornamentação Alegórica." In: BARBUY, Heloisa (Org.). Museu Paulista. Um monumento no Ipiranga história de um Edifício Centenário e sua recuperação, 1997. p 267ss. BREFE,Ana Claudia Fonseca.Um Lugar de Memória para a Nação.O Museu Paulista reinventado por Affonso d'Escagnolle Taunay (1917-1945). Tese (Doutorado) - Departamento de História, Unicamp, 1999.A tese faz uma análise cuidadosa das relações entre a historiografia de Taunay, sua atuação como diretor do Museu Paulista e a decoração, porém não investiga a questão da linguagem visual, propriamente dita, adotada por Taunay na realização de seu projeto.

2. ELIAS, Maria José. Museu Paulista, memória e história. 1996,p. 205.Tese (Doutorado) - Faculdade 
de Filosofia,Letras e Ciências Humanas, Universidade de São Paulo, São Paulo, 1996.

3. SEVCENKO, Nicolau "Museu Paulista: História, Mito e Crítica." In: ÀS MARGENS do Ipiranga, op. cit., p. 23.

4. Faz-se necessário aqui relembrar a tradicional vinculação da família Taunay com o mundo das artes, a fim de descartar uma interpretação ingênua da relação de Affonso Taunay com as imagens, em especial com a pintura. Estamos certamente diante de um tema complexo, onde valores estéticos e concepções originárias de sua formação de historiador concorrem para a estruturação de um programa visual bastante sofisticado. Não há dúvidas de que Taunay via a pintura como um meio de legitimação de sua visão da história. Como bem apontaram Solange Ferraz de Lima e Vânia Carneiro de Carvalho em seu texto "São PauloAntigo, uma encomenda da modernidade: as fotografias de Militão nas pinturas do Museu Paulista" Anais do Museu Paulista, Nova Série, n. 1, 1993, p. 147-178, o quadro a óleo era para o diretor do Museu Paulista um fator de legitimação das imagens apresentadas como documentos de uma época. Como nos mostram as autoras, ele privilegiava a pintura à fotografia na realização da tarefa de "significar" a "realidade" para o espectador.

5.Affonso Taunay nasceu em 1876, quando o pai exercia o cargo de presidente da província de Santa Catarina, tendo se transferido já no ano seguinte para a Corte no Rio de Janeiro. cf. MATTOS, Odilon Nogueira de. Affonso de Taunay: historiador de São Paulo e do Brasil. São Paulo: Coleção Museu Paulista, 1977. (Série Ensaios, v.1). todas as forças reunidas para conquistar o conjunto do país e, graças a seu impulso e energia, arrastar esse país a seu destino de grande civilização. ${ }^{3}$

Tal abordagem político-ideológica é sem dúvida certeira e fundamental. Porém, ao se concentrar no conteúdo propriamente dito do programa decorativo, ela deixa de discutir outra questão igualmente importante, vale dizer, a das apropriações que Taunay fez da linguagem visual e de sua tradição específica no processo de tradução de suas convicções teóricas em um programa iconográfico específico ${ }^{4}$. Mais ainda, procuraremos demostrar aqui que foi justamente nesse processo de tradução, isto é, de passagem do medium da escrita para o medium visual, que se deu a construção definitiva do seu programa, tal como o conhecemos hoje, e portanto sem a análise desse processo de tradução o programa não pode ser totalmente compreendido.

Affonso D'Escragnolle Taunay, filho de Alfredo D'Escragnolle Taunay, o visconde de Taunay, e bisneto do artista Nicolau Antoine Taunay, que chegara juntamente com a missão francesa de D. João VI ao Brasil em 1816, pertencia a uma família de políticos, intelectuais e artistas. Seu bisavô fora um dos fundadores da Academia Imperial de Belas Artes no Rio de Janeiro, e seu avô, Felix Emil Taunay, continuara a profissão do pai, substituindo-o na cadeira de pintura da mesma instituição, em 1819. Alfredo D'Escragnolle Taunay, filho de Felix Emil, exercera por sua vez importantes atividades políticas, militares e literárias. Participara da Guerra do Paraguai, tendo sido também deputado federal e presidente de duas províncias: Santa Catarina ${ }^{5}$ e Paraná. Tornou-se ainda membro efetivo da Academia Brasileira de Letras, após a publicação de seu principal romance Inocência, e exerceu intensa atividade jornalística em seus últimos anos de vidab.

Affonso Taunay cresceu no Rio de Janeiro, tendo recebido educação humanística no Colégio Pedro II, ingressando em seguida na Escola Politécnica, pela qual recebeu o diploma de engenheiro civil. Chegou a São Paulo na virada do século para lecionar na Escola Politécnica paulista a convite de seu tio, Augusto Carlos da Silva Teles, onde permaneceu pelo resto de sua vida.

Apesar de sua profissão de engenheiro, Affonso Taunay manteve desde cedo grande interesse pelas ciências humanas, em especial pela história, publicando, a partir de 1910, artigos sobre os viajantes europeus, sobre a Missão Francesa de 1816 e sobre o Segundo Reinado?. Em 1917, ao ser convidado para assumir o cargo de diretor do Museu Paulista, Taunay já era um historiador consagrado e sua opção profissional marcaria definitivamente o novo perfil que ganharia o Museu.

Durante a gestão von Ihering, o "Palácio Bezzi"8 possuía uma função dupla: por um lado, não deixara de ser monumento à Independência, aspecto ressaltado por sua arquitetura imponente e pela presença do famoso quadro de Pedro Américo9 "Independência ou Morte!", que se encontrava desde 1895 no salão de honra do Museu. Por outro, funcionava como museu de ciências naturais, função esta que não se refletia no caráter do prédio. $\bigcirc$ museu de von lhering utilizava apenas o espaço físico do edifício, sem qualquer atenção a seu caráter simbólico.

Ao assumir a diretoria do Museu Paulista, Taunay abraçou a missão de configurar uma unidade entre a arquitetura representativa e a função da instituição. Não podendo expulsar de uma só vez as coleções de ciências naturais, ele implantou uma política persistente de valorização da coleção histórica do Museu, reforçando o vínculo desta coleção com a arquitetura e com a proposta originária 
de Bezzi $^{10}$. $O$ programa de decoração interna do edifício para a celebração da passagem do centenário da Independência, que ele começou a idealizar pouco tempo após seu ingresso no cargo de direção da instituição, pode ser considerado, desse ponto de vista, o carro chefe de seu projeto para o Museu Paulista como um todo.

\section{Programa Decorativo}

Para a maioria do público que visita o Museu Paulista hoje, passará talvez despercebida a complexidade e sobretudo a coesa unidade da decoração apresentada no hall de entrada, na escadaria e no salão nobre do Museu, para não mencionar a ligação deste programa com o projeto de Taunay para as "salas de iconografia paulista", antes situadas na ala oeste do museu e hoje profundamente alteradas em seu conteúdo. A estátua de D. Pedro I, posicionada em um grande nicho acima da escadaria, ajuda certamente o visitante a situar esta decoração no âmbito de um memorial à Independência, porém ele dificilmente adivinhará sua relação com as duas enormes figuras de bandeirantes situadas à direta e à esquerda do imponente saguão de entrada, ou atribuirá qualquer conotação especial às ânforas da escadaria. Nesse sentido o projeto decorativo de Taunay pode ser considerado até certo ponto difícil de acessar, ainda que se apresente em toda a sua lógica e coerência para os que se familiarizam com ele. Sem dúvida foi na intenção de educar e "iniciar" o público que Taunay publicou em 1937 o seu Guia da Secção Histórica do Museu Paulista, onde ele descreve minuciosamente o significado simbólico de cada elemento desta sofisticada decoração. Para fins deste artigo, faremos apenas uma rápida descrição dos principais elementos desse programa, de forma a permitir uma melhor visualização do objeto de nosso interesse.

Como bem salientou Cecília H. de Salles Oliveira, a decoração faz "[...] do eixo central do prédio um 'caminho' demarcado por etapas supostamente percorridas pela história de São Paulo e do Brasil, que, iniciando-se na 'fase colonial', encontra seu desfecho na emergência da 'nação'"l1.

A relevância que assume o Estado de São Paulo, com o bandeirantismo, dentro da "história" da Independência contada por Taunay, é uma das características centrais deste conjunto decorativo. O autor do projeto pretendeu atribuir a São Paulo, através do movimento Bandeirante o papel de conquistador e unificador do território da nação brasileira. Tal mensagem é transmitida através da orquestração de elementos distintos da decoração, que descreveremos sucintamente a seguir.

\section{Hall de Entrada}

Já à entrada do Museu, o visitante depara-se com duas grandes estátuas de bandeirantes, à direita e à esquerda, executadas pelo escultor Luigi Brizzolara ${ }^{12}$. "Simbolizam dois grandes ciclos bandeirantes: o da caça ao índio e devassa do sertão, representado por Antônio Raposo Tavares, e o do ouro e pedras preciosas,
6. Cf. Odilon Nogueira de Mattos, op. cit., p. 25

7. Cf. Elias, op. cit., p. 234235. O primeiro trabalho historiográfico de Taunay foi publicado em 1910 sob o título Crônicas do Tempo dos Felipes. Tratava-se de um romance histórico, que lhe abriu as portas do Instituto Histórico e Geográfico Brasileiro, no qual foi admitido como membro em 1911.Cf.Mattos,op. cit., p. 26.

8. O Monumento do Ipiranga era assim denominado na época em homenagem ao arquiteto que o construiu, o italiano Tommaso Gaudenzio Bezzi.

9. Pedro Américo (1843 1905). Um dos principais pintores do período do Império,estudou naAcademia Imperial de BelasArtes, partindo para Paris como pensionista do imperador em 1859. Em 1864 retornou da Europa para tornar-se professor da cadeira de desenho na Academia.Ao longo de sua vida transitou freqüentemente entre o Rio de Janeiro e Florença, cidade onde veio a falecer.

10. Taunay via seu projeto de decoração interna do Museu Paulista como a retomada dos trabalhos de conclusão do monumento de Bezzi que, segundo ele, tinham sido lamentavelmente abandonados anos antes por motivos financeiros: "Faltavam-lhe os devidos remates decorativos, a inscrição do frontão, as esculturas do tímpano, as estátuas coroadoras do edifício, como aliás continuam a lhe faltar", comenta o autor, exprimindo ainda seu desejo de ver esse trabalho um dia concluído.TAUNAY, E. Guia da secção bistórica do Museu Paulista.São Paulo:Imprensa Oficial do Estado, 1937.

11. Cecília Helena de Salles Oliveira "O Museu Paulista e o Imaginário da Independência." In: MUSEU PAULISTA: novas leituras. 
São Paulo:Museu Paulista/ USP, 1995. p. 5-9

12. Luigi Brizzolara (1868 - 1937). Escultor italiano que, embora residente $\mathrm{em}$ Genova, executou várias encomendas para patronos paulistas, como o Mausoléu da Família Matarazzo no Cemitério da Consolação. Obteve o segundo lugar no Concurso para o Monumento da Independência em 1919, tendo sido considerado o favorito pela opinião pública.

13. TAUNAY. Guia da secção bistórica do $\mathrm{Mu}$ seu Paulista, op.cit.,p. 57.

14. Rodolfo Bernardelli (1852 - 1931). Nascido no México, chegou com a família ao Brasil em 1866. Foi aluno de Chaves Pinheiro na Academia Imperial de Belas Artes do Rio de Janeiro, tendo estudado em Roma entre 1870 e 1876. Após a queda do Império e do advento da República, tornou-se o primeiro diretor da nova Escola Nacional de Belas Artes.

15. TAUNAY Guia da secção Histórica do $\mathrm{Mu}$ seu Paulista, op.cit.,p.57.

16. Id.

17. Id. Henrique Bernardelli (1858 - 1936). Irmão mais moço de Rodolfo Bernardelli, exerceu atividades de pintor e desenhista, foi aluno de Victor Meirelles, Zeferino da Costa e Agostinho da Motta, entre outros na Academia Imperial de Belas Artes do Rio de Janeiro,ganhando o prêmio de viagem à Itália em 1879 . Entre 1880 e 1886 estudou com Domenico Morelli em Roma, retornando ao Brasil em 1886. Durante a República, tornou-se professor da Escola Nacional de Belas Artes (ENBA). João Batista da Costa (1865 - 1926), pintor de paisagem, ingressou na Academia Imperial de Belas Artes em 1886 , tendo estudado com Zeferino da Costa e Rodolfo Amoedo, entre por Fernão Dias Paes." "13 Elas introduzem a importância do tema dos Bandeirantes, não só pela posição que ocupam, mas acima de tudo pelos seus tamanhos, que ultrapassam mesmo as dimensões da estátua central de D. Pedro. Ainda no saguão, quadros e brasões falam do período colonial.

\section{Escadaria (FIGURAS 1-3)}

Após o estabelecimento do Bandeirante como o principal símbolo de progresso no percurso que levou o Brasil da era colonial à Independência, encontramos na escadaria e no espaço que a circunda, o corpo central do conjunto decorativo de Taunay. No nicho principal aparece a estátua de D.Pedro I, executada por Rodolfo Bernardelli i4, que "representa o príncipe no momento em que tendo arrancado o tope português, vai soltar o brado de Independência ou Morte!"15 Ao longo da escadaria situam-se dezoito ânforas contendo as águas de rios que circunscrevem o território nacional, acrescidos de mais duas ânforas com uma mistura de águas dos rios dos extremos norte e sul e leste e oeste do país. Esta delimitação fluvial do território reforça o tema do bandeirantismo como elemento fundamental para a criação da nação brasileira.

Ao nível do pedestal da estátua de D. Pedro l encontramos novamente presentes figuras de bandeirantes, em número de seis ao todo. "[...] Cada uma delas simboliza uma das unidades da federação que se destacaram do território de São Paulo. [...] Em cada pedestal se inscreve o nome do Estado e a data de sua separação de São Paulo." 16

Entre as estátuas de D. Pedro I e as dos bandeirantes, encontram-se painéis recordando fases capitais da nossa história nacional: o ciclo da caça ao índio, por Henrique Bernardelli, os dos criadores de gado, pelo mestre João Batista da Costa, o do ouro, do Prof. Rodolfo Amoedo, e a tomada de posse da Amazônia por Pedro Teixeira, do Prof. Fernandes Machado. ${ }^{17}$

Entre os nichos e a sanca encontram-se ainda seis retratos e efígies de figuras de importância - na concepção de Taunay - no processo de Independência da nação. Os retratos se sucedem também ao longo da sanca, em grandes painéis de arco abaulado.

\section{Salão Nobre (FIGURA 4)}

A principal peça desta sala é sem dúvida o quadro de Pedro Américo Independência ou Morte! (FIGURA 6) que, como dissemos, encontrava-se presente na mesma desde 1895, ou seja, muito antes de Taunay desenvolver o seu programa decorativo. O caráter geral do salão já estava, portanto, previamente estabelecido. Taunay acrescentou a esses cinco medalhões dois painéis de autoria de Domenico Failutti ${ }^{18}$, e dois quadros históricos executados por Oscar Pereira da Silva ${ }^{19}$, representando respectivamente a fragata União com D. Pedro a bordo ordenando a partida dos lusitanos e uma Sessão das Cortes em Portugal, na qual "brasileiros fazem frente ao partido recolonizador que quer votar medidas opressivas ao 


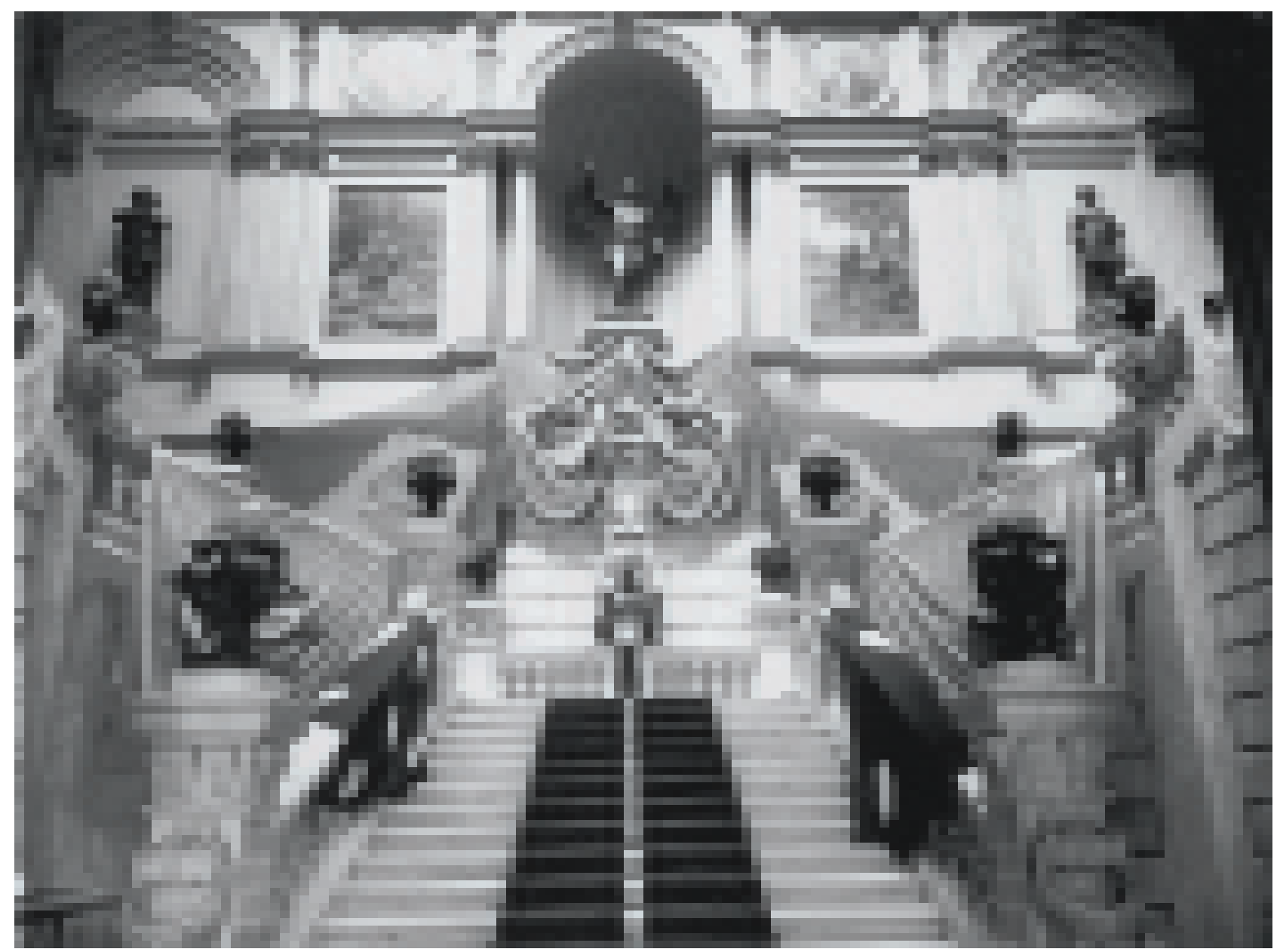

FIGURA 1 - Escadaria monumental vista a partir do hall de entrada do edifício do Museu Paulista na década de 1930, com a estátua de D. Pedro I ocupando o nicho central da escadaria, negativo de vidro. Acervo Museu Paulista da USP. Reprodução com restauração óptica de João Sócrates. 


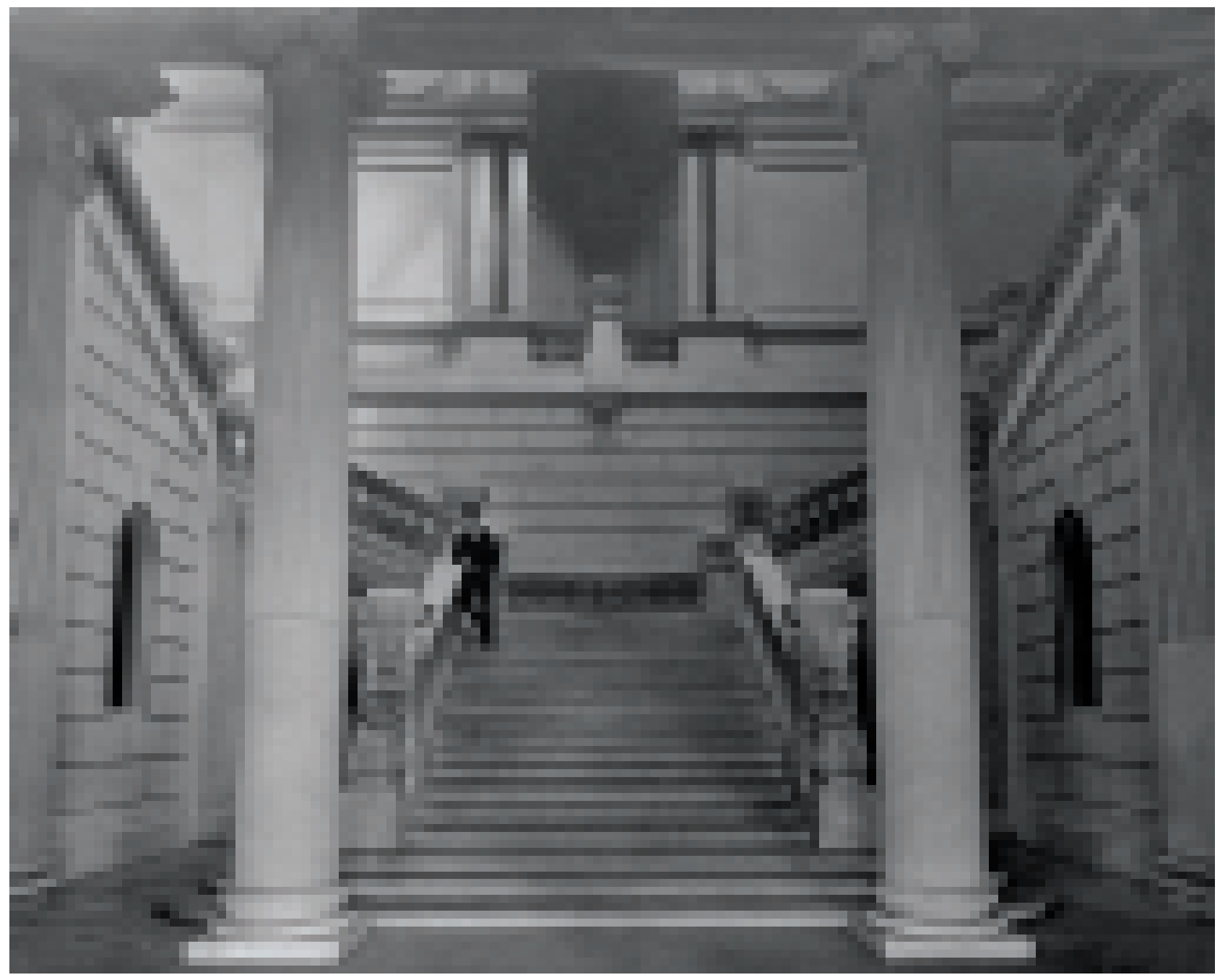

FIGURA 2 - Escadaria central do edifício do Museu Paulista, vista a partir do hall de entrada. Vê-se o engenheiro Bezzi, que projetou o edifício, fotografia de Guilherme Gaensly, 1892, albumina. Acervo Museu Paulista da USP. Reprodução com tratamento óptico de João Sócrates de Oliveira. 


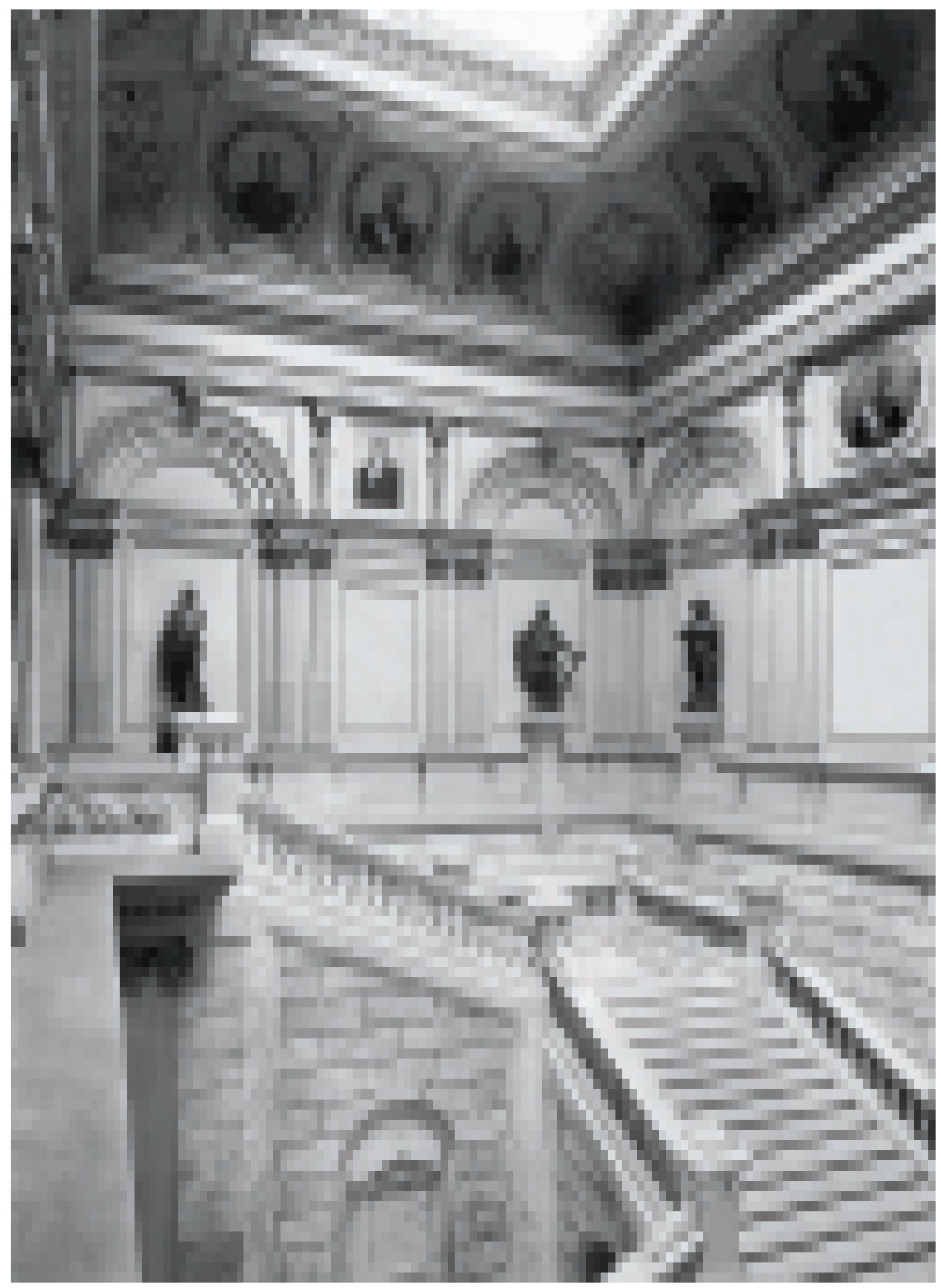

FIGURA 3 - Escadaria monumental do Museu Paulista com a decoração incompleta, c. 1920, negativo de vidro. Acervo Museu Paulista da USP. Cópia-contato de José Rosael. 


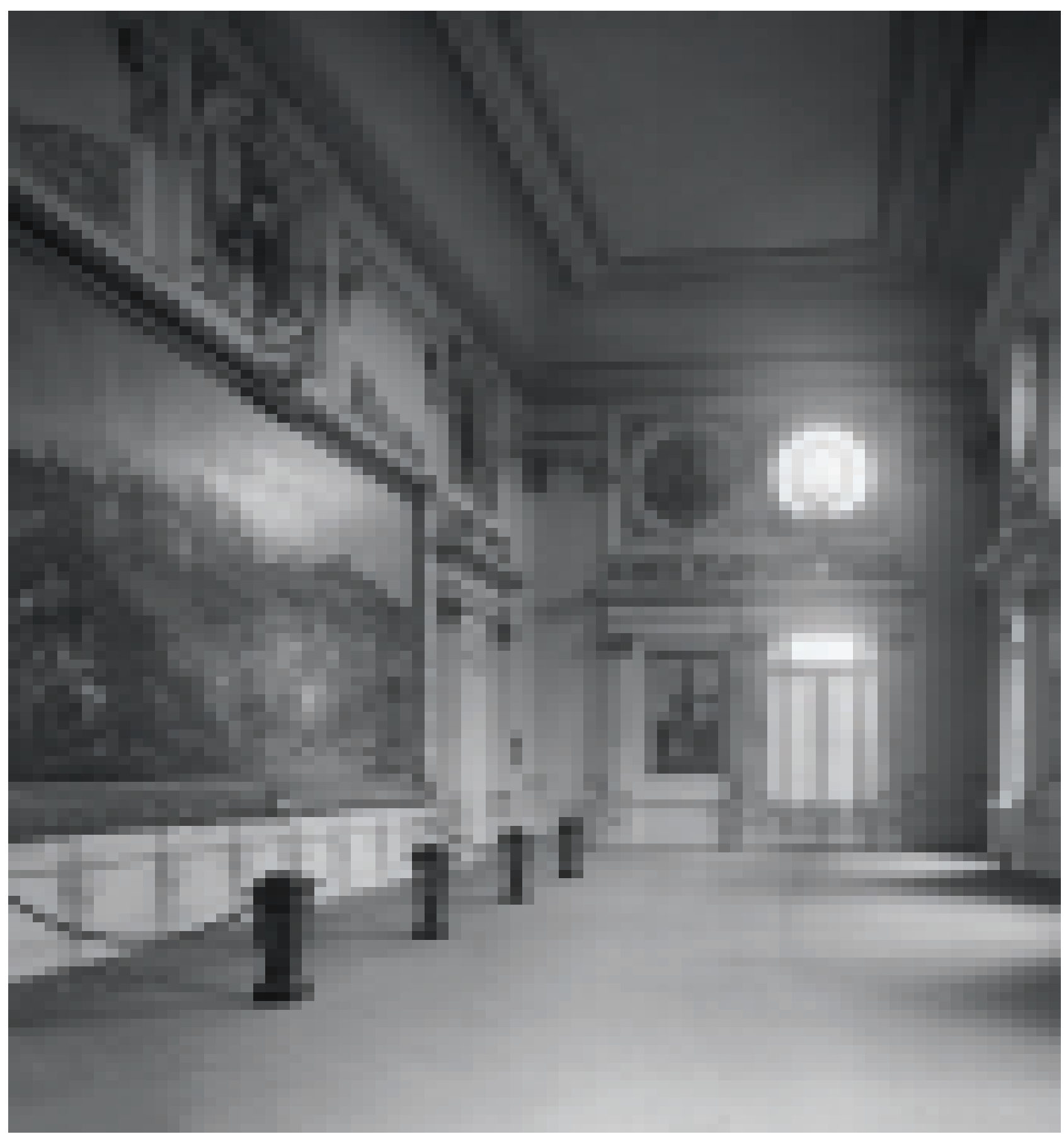


Brasil"20. Além desses elementos, Taunay organizou na sala uma série de documentos e objetos pessoais relacionados a D. Pedro, à sua família e a eventos da Independência.

Salas de Iconografia Paulista (FIGURA 5) 21

Completando, por assim dizer, esta decoração, que ocupa o corpo central do edifício, Taunay projetou a criação de dezesseis salas de exposições, sendo oito delas (todas situadas na ala oeste do andar térreo do prédio) dedicadas outros. Em 1896 viajou para a Europa, onde permaneceu até 1899 , tendo estudado na Académie Julien em Paris. Torna-se professor da ENBA em 1906, onde lecionou até sua morte. Rodolfo Amoedo $(1857$ - 1941). Nascido na Bahia, chegou em 1868 ao Rio de Janeiro, ingressando como aluno da Academia em 1874. Em 1879 viajou para Paris, como pensionista do Império, estudando na Académie Julien e na

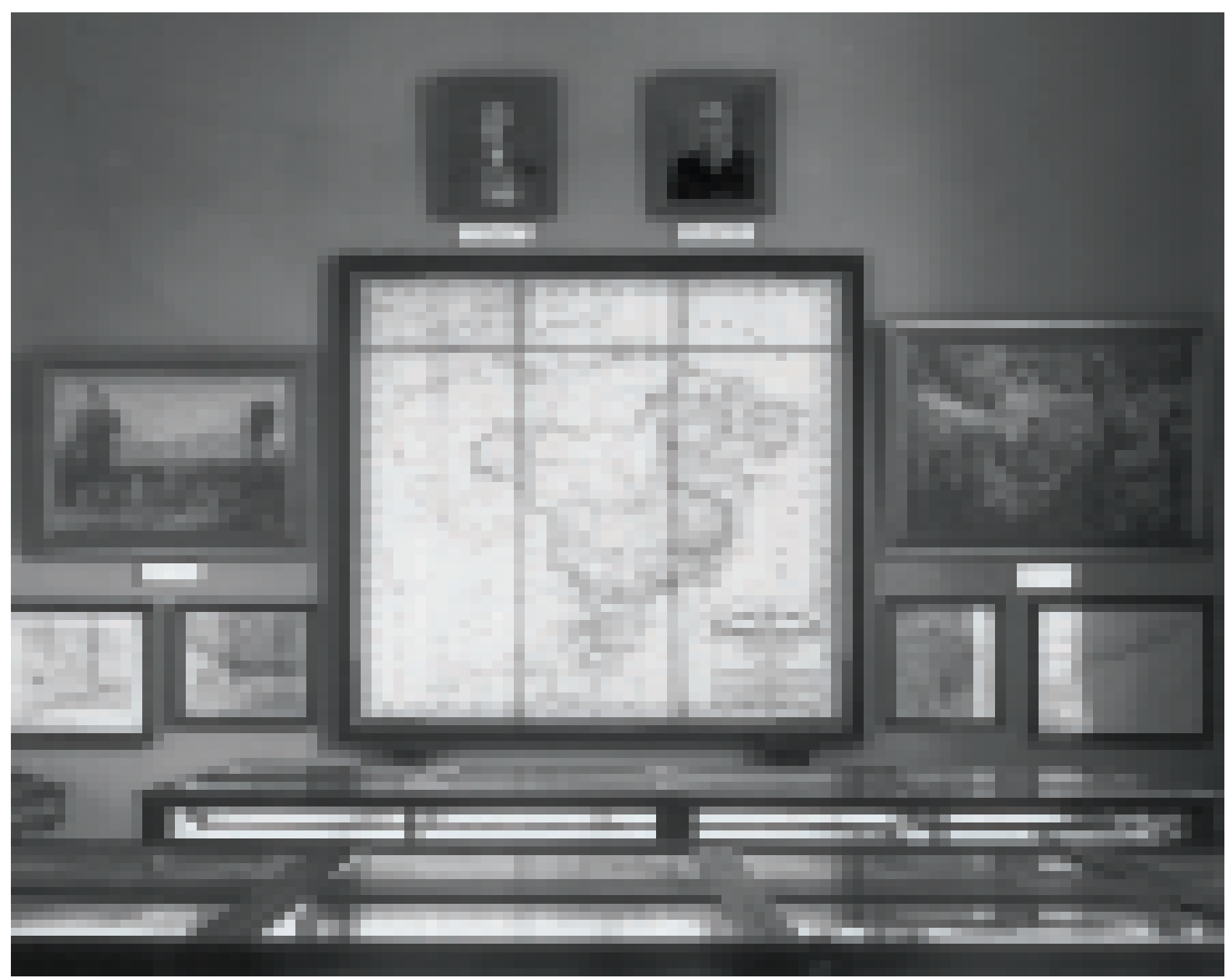

FIGURA 5 - Sala da Cartografia Colonial e Documentos Antigos, em exposição intitulada Iconografia Paulista, organizada por Afonso de E. Taunay, quando diretor do Museu Paulista (1917-1946), s/d., negativo de vidro. Acervo Museu Paulista da USP. Cópia-contato de José Rosael. 
École National Supérieure des Beaux-Arts de Paris. Retornou ao Brasil em 1887, tornando-se professor da Academia no ano seguinte. Joaquim Fernandes Machado nasceu em 1875 no Rio de Janeiro. Foi aluno da Academia e pensionista do Estado em Paris durante dois anos; retornando ao Brasil, prosseguiu uma carreira como pintor, ligado à ENBA.

18. Domenico Failutti (1872 - 1923). Pintor retratista de origem italiana, estudou em Udine e na Academia de Veneza, tendo em seguida trabalhado em diversos países europeus, assim como também na Venezuela, nos Estados Unidos e no Brasil.

19. Oscar Pereira da Silva (1867 - 1939). Estudou pintura naAcademia entre 1882 e 1887 , tendo sido aluno de Zeferino da Costa, de quem foi assistente na decoração da igreja da Candelária.Viajou para $\mathrm{Pa}$ ris em 1889 , retornando em 1896 para radicar-se em São Paulo, onde lecionarou e trabalharou até sua morte.

20. TAUNAY. Guia da secção Histórica do $\mathrm{Mu}$ seu Paulista, op.cit.,p.57.

21. Adotei esse nome genérico para falar do conjunto das salas organizadas porTaunay na ala oeste do primeiro andar do edifício. Esse título não se encontra, portanto, nas descrições de Taunay, que se referiu a cada uma delas separadamente.

22.A ala leste não era tão coesa em sua organização global como a oeste. Suas salas foram dedicadas, em parte, a grandes vultos nacionais, como Santos Dumont e Bartolomeu Lourenço Gusmão e, em parte, a objetos comemorativos ou significativos da história nacional, como armas, fardas, indumentária antiga e numismática. à história paulista e suas articulações com a história nacional, cujos temas eram os seguintes: 1) Sala das Monções, 2) Sala da Cartografia Colonial e Documentos Antigos, 3) Sala consagrada ao passado da cidade de São Paulo, 4 e 5) Salas de antiga iconografia paulista, 6) Mobiliário brasileiro antigo e retratos antigos, 7) Sala consagrada ao passado da cidade de São Paulo, 8) Arte primitiva, arte religiosa colonial e mobiliário antigo 22 .

Com exceção das "salas de iconografia paulista", a breve descrição feita acima, a partir da descrição efetuada pelo próprio Taunay em 1937, corresponde em larga medida à situação atual. Porém, em 1917, quando Taunay começou a fazer as primeiras encomendas para a decoração do edifício, este programa estava longe de sua forma definitiva. De fato, podemos falar de etapas no processo de implantação do programa, que significaram, ao mesmo tempo, importantes modificações na própria retórica do conjunto. Seria correto dizer que, de uma forma geral, a versão da História que Taunay buscou articular visualmente na decoração do Museu Paulista pouco se transformou ao longo dos quase trinta anos de sua gestão como diretor daquela instituição ${ }^{23}$. Porém, a forma de tradução de suas convicções teóricas em um programa visual sofreu grandes alterações. Somente aos poucos e na prática Taunay alcançou uma forma definitiva para o seu programa, que permitiria expressar plenamente suas idéias sobre o papel de São Paulo no processo de formação da nação brasileira. Acompanhar esse processo é o que nos interessa aqui, buscando discriminar mais exatamente as diferentes apropriações que Taunay faria da tradição da História da Arte, tanto brasileira, quanto européia, até conseguir adequá-la suficientemente às suas intenções de historiador-ideólogo.

Taunay e sua versão da História

Engenheiro de formação e professor da Escola Politécnica de São Paulo, Taunay iniciou sua carreira de historiador em 1910, com a publicação de sua Crônicas do Tempo dos Felipes. No ano seguinte, ele se tornaria membro do Instituto Histórico e Geográfico Brasileiro (IHGB) e de sua versão regional: o Instituto Histórico e Geográfico de São Paulo (IHGSP), ambos marcados por uma visão de história positivista e historicista ${ }^{24}$. A acentuada ênfase na documentação como fonte privilegiada de acesso do historiador ao fato, implícita nessa visão, era inteiramente compartilhada por Taunay que, em seu Os Princípios Gerais da Moderna Crítica Histórica, se declararia partidário da nova historiografia francesa, representada por Charles-Victor Langlois e Charles Seignobos ${ }^{25}$. Os dois autores, opondo-se a historiadores como Ranke e Taine, buscavam desenvolver uma visão de história evolutiva, privilegiando uma "história das civilizações", em oposição à história dos grandes homens. Assim, Taunay também falaria de uma "História da Civilização Brasileira", em oposição a uma "história-batalha". Rememorando a aula inaugural de Taunay na Faculdade de Filosofia, em 1934, Odilon Nogueira de Mattos diria de seu professor:

Ao assumir a regência da nova cadeira da Faculdade de Filosofia da Universidade de São Paulo, Afonso Taunay fez questão de salientar que seu curso seria, não de História do Brasil, mas de História da Civilização Brasileira, e em sua aula inaugural lembrou que um 
curso da natureza do que pretendia ministrar era absoluta novidade no meio cultural paulista, pois nossos professores e historiadores só se preocupavam com a história episódica, puramente fatual, sem a mínima atenção para com o aspecto interpretativo e, ainda assim, com ênfase quase exclusiva para os aspectos políticos e administrativos. Chegou a usar para caracterizar nossa historiografia uma pitoresca expressão, muito do gosto dos franceses: história-batalha, com a qual se designava aquele tipo de história, que muita gente ainda faz, que só cuidava dos fatos isolados, nas suas mínimas peculiaridades, mas sem que se tirasse deles uma linha interpretava ou sequer explicativa. ${ }^{26}$

Ao mesmo tempo, a produção de Taunay adequava-se aos ideais do IHGSP, na medida em que, desde muito cedo, ele se voltara, aconselhado por seu professor Capistrano de Abreu, a pesquisas sobre a história de São Paulo, e mais particularmente sobre sua relevância para a história nacional ${ }^{27}$. É exatamente nesse contexto que o bandeirantismo toma uma importância cada vez maior em sua obra, tornando-se o núcleo articulador de sua versão da construção do Brasil.

Taunay não foi o primeiro a usar o mito bandeirante como metáfora para enaltecer o "povo" paulista. Ao longo da década de 20, ela era comumente empregada para diferenciar paulistas do enorme contingente de estrangeiros que havia chegado à região ${ }^{28}$, assim como para dar a estes um caráter nobre, uma "pureza racial", ausentes no litoral29. Porém, ele foi um dos primeiros a dar às bandeiras o papel de construtora da nação. Isso só pôde ser feito através da aplicação de sua noção evolutiva de história ao tema particular do bandeirante, através da qual essa história se tornaria a história da formação do território nacional e, portanto, a narrativa do nascimento do Brasil. Taunay apresentou essa compreensão inusitada do bandeirantismo ao público em 1924, no primeiro tomo de sua História Geral das Bandeiras, portanto logo depois da conclusão da primeira etapa da decoração do Museu Paulista, em 1922. Assim, tudo leva a crer que era essa também a concepção de história na qual se ancorava o projeto iconográfico do Museu. No entanto, como veremos, a tradução completa de tais idéias em imagens só ocorreria lentamente, evidenciando-se de forma plena apenas em 1937. Alguns fatores concorreram para que tal dificuldade de transposição ocorresse, entre os quais o próprio caráter de monumento que marcara o edifício desde sua origem e a existência de uma decoração parcial anterior à intervenção de Taunay, como a presença do grande quadro de Pedro Américo "Independência ou Morte!" no salão nobre do edifício.

\section{A Decoração do Museu Paulista como projeto para a celebração do centenário da Independência}

Quando Taunay assumiu a diretoria do Museu Paulista em 1917 e começou a projetar a decoração do prédio, sua intenção era terminar os trabalhos em 1922, a tempo de apresentá-la ao público como parte das comemorações do centenário da Independência. Temos portanto, nesse período, a implementação de um primeiro programa visual - documentado através das sucessivas encomendas feitas aos artistas e das prestações de contas de Taunay aos seus superiores: o secretário do Interior e o presidente do Estado ${ }^{30}$-, que não corresponde inteiramente ao que conhecemos hoje.
23.Taunay foi o diretor do Museu Paulista entre os anos de 1917 e 1945.

24. Para uma análise aprofundada do IHGB ver SCHWARCZ,Lilia.Oespetáculo das raças - cientistas, instituições e questões raciais no Brasil: 1870 1930. São Paulo: Companhia das Letras, 1993

25. Cf. Brefe, op.cit., p. 50.

26. Odilon Nogueira de Mattos comenta ainda, mais adiante:"O programa que Taunay elaborou para a nova Faculdade de Filosofia [...] constitui excelente roteiro para o estudo de nossa evolução histórica." Cf. Nogueira de Mattos, op. cit., p. 41.

27.Por ocasião da morte de Capistrano, escreveu Taunay: "Se você está em São Paulo e quer escrever história - aconselhou-me certa vez o meu querido e saudosíssimo mestre Capistrano deAbreu - faça uma coisa: estude as bandeiras."Cf.Taunay,"J.Capistrano de Abreu in Memoriam". Anais do Museu Paulista, t. 3, p. XVII, 1927.

28. Brefe, op. cit., p. 183.

29. Como apontou Luiz da Costa Lima Terra Ignota. A construção de Os sertões. Rio de Janeiro: Civilização Brasileira, 1997, a idéia do paulista como representante de uma "raça pura", em oposição às "sub-raças" que ocupavam a região do litoral, já se encontra expressa nos Sertões de Euclides da Cunha. Parafraseando o autor, diz Costa Lima:"Dos paulistas, singularizados por sua participação nas expedições que desbravaram os sertões, em cruzamento com os indígenas, se originaram as populações interioranas do Nordeste. Teriam sido elas, além do mais, beneficiadas pela disposição topográfica da região: vencida a Serra do Mar, as populações sertanejas passaram a estar in- 
suladas, assim não sofrendo 'o apego irrepreensível ao litoral'. As condições mesológicas, portanto, constituíram 'um isolador étnico e um isolador histórico'”, p. 40

30. A documentação referente ao desenvolvimento do programa decorativo, principalmente cartas trocadas com os artistas e prestações de contas ao secretário do Interior, estão preservadas no arquivo do Museu Paulista e constituem a fonte principal da pesquisa apresentada aqui.

31.Wasth Rodrigues (1891 -1957). Pintor e historiador, foi pensionista do governo do Estado de São Paulo em Paris a partir de 1910, estudando na Académie Julien e na Escola de Belas Artes. Retornando ao Brasil em 1914, realizou diversas pesquisas de caráter histórico que passara a servir de base para a sua produção artística.

32. "Existem no grande salão de honra lugares de propósito deixados pelo arquiteto para receber pinturas e retratos de vultos notáveis cuja memória se procede aos fatos de 1822 . Portanto, farei executar esses retratos pelos nossos mais ilustres pintores brasileiros, entre outros Henrique Bernardelli,Amoedo, Batista da Costa, muito pouco representados até agora em São Paulo.Assim se junta em nosso proveito a intenção patriótica nacional." Carta de Taunay a Henrique (?), 26/1/1920, Fundo Museu Paulista/Museu Paulista/USP.

33. Amoedo escreveria a Taunay, respondendo a uma carta sua com a indicação de uma estampa de Debret que poderia ajudar na composição do quadro da imperatriz:

"O fato de existir uma estampa de Debret representando a personagem em corpo inteiro, em nada suaviza o meu trabalho, pois fatalmente eu teria de consultá-la como um docu-
Inicialmente Taunay havia dividido a decoração do Museu em dois grandes grupos: para as cenas de São Paulo, nas "salas de iconografia paulista", ele planejou, desde o início, fazer encomendas a artistas paulistas, ligados ao Liceu de Artes e Ofícios, como Wasth Rodrigues, ${ }^{31}$ Benedito Calixto e Oscar Pereira da Silva. A decoração do corpo do edifício, isto é, hall de entrada, escadaria e salão nobre, por sua vez, deveria ser executada por professores da Escola Nacional de Belas Artes, artistas nacionais de grande prestigio ${ }^{32}$. Porém esse projeto teve de ser reestruturado, diante das dificuldades surgidas durante sua implementação efetiva. Logo de início, Taunay procurou manter um estreito controle sobre a composição dos painéis encomendados aos pintores cariocas, como ele vinha fazendo com os quadros encomendados aos pintores paulistas, o que gerou conflitos com os artistas, que se sentiam muitas vezes desrespeitados em sua condição de profissionais, como no caso da polêmica em torno do quadro retratando a "Imperatriz", inicialmente encomendado a Amoedo 33. Ao mesmo tempo, podemos acompanhar os esforços dos artistas paulistas para receber encomendas importantes do Museu Paulista. Assim, depois de já terem recebido a encomenda para a pintura dos retratos da sanca, Oscar Pereira da Silva e Domenico Failutti apresentaram uma proposta para Taunay que incluía vários painéis para o salão nobre. Devido portanto a questões de preço e controle sobre a execução dos trabalhos, Taunay terminou por desistir parcialmente de seu projeto inicial, entregando a decoração do salão nobre também a Failutti e Oscar Pereira da Silva. As encomendas para os grandes artistas brasileiros da Escola Nacional de Belas Artes passaram, então, a se restringir à "Escadaria Monumental".

Por fim, em linhas gerais, a decoração estruturou-se da seguinte forma nesse primeiro momento:

Estatuária: Duas estátuas de mármore retratando "Fernão Dias Paes Leme" e "Raposo Tavares", por Luigi Brizzolara, no hall de entrada; "D.Pedro I", de autoria de Rodolfo Bernardelli, que deveria ocupar o nicho central da escadaria, ${ }^{34}$ e seis estátuas de bandeirantes em bronze ao longo dessa, de autoria dos artistas Nicola Rollo ${ }^{35}$, Amadeo Zani3 ${ }^{36}$ e Henri von Emelen ${ }^{37}$.

Pintura: Não havia qualquer pintura no hall de entrada. Na escadaria, Taunay planejara a instalação de quatro painéis, encomendados a professores da Escola Nacional de Belas Artes - "Mineração" (retrato de Fernão Dias Paes) e "Varação" 38, de Rodolfo Amoedo, "O Bandeirante" (retrato de Mathias Cardoso de Almeida), de Henrique Bernardelli, e "Pedro Teixeira", de Fernandes Machado — e de quatro retratos: "Tiradentes" e "José Domingues Martins", por Oscar Pereira da Silva, "José Joaquim Rocha" e "Januário Barbosa", por Domenico Failutti. Acima desses, 18 retratos de políticos que tiveram um papel relevante no processo de Independência, de autoria de Oscar Pereira da Silva e Failutti. No Salão Nobre: o quadro de Pedro Américo, cinco retratos: "Diogo Feijó", "José Clemente Pereira", "Pedro I", "José Bonifácio", "Gonçalves Ledo", por Oscar Pereira da Silva, dois painéis históricos do mesmo autor: "D. Pedro a Bordo da Fragata União" e "A Sessão das Cortes" e os "Retrato de Maria Quitéria" e "Retrato da Imperatriz", de Domenico Failutti.

Apesar de todas as alterações nos planos iniciais de Taunay que obliteravam a marcante diferença entre o grupo de obras inicialmente pensado como encomenda para os artistas cariocas e aquele pensado para os artistas do Liceu de Artes e Ofícios, ainda podemos identificar, como dissemos, uma certa divisão interna da decoração em dois grandes blocos, à qual corresponderiam 
dois modelos históricos e iconográficos distintos. Essa diferença acabava por pontuar uma outra diferença qualitativa entre sentimentos de identidade local e nacional.

De fato, a condição de monumento do edifício e a necessidade de decorá-lo em conformidade com sua função punham a decoração de Taunay em conflito com suas visões de historiador, conflito este que ele não conseguiu resolver no nível da iconografia, pelo menos antes de 1922. Como espaço de celebração da Independência, o prédio exigia uma decoração que pontuasse a importância desse ato e, mais ainda, a presença do quadro de Pedro Américo induzia Taunay a lançar mão do consagrado gênero da pintura histórica e da retratística para desenvolver o discurso na parte central do edifício. Por outro lado, seu interesse pela história de São Paulo, por sua cultura material, inclinava-o a procurar para a decoração um modelo visual que equivalesse aos princípios e métodos historiográficos de seus livros, os quais, como vimos, pressupunham a idéia de transformação lenta, de continuidade e de evolução histórica.

Buscando uma solução para tal impasse, Taunay terminou sacrificando a unidade de conjunto da decoração e adotando dois modelos iconográficos distintos: um para o corpo central do edifício e outro para as "salas". Vale notar que, diante dessa escolha, Taunay situava o seu futuro visitante de forma diferente diante da história nacional e da história local. Assim, se por um lado a história de "grandes vultos" desenvolvida no plano central do edifício, apoiando-se no princípio da exemplus virtutis, exigia uma atitude moral do espectador, ao mesmo tempo em que o excluía da escritura da História, por outro, o discurso sobre São Paulo favorecia um sentimento de proximidade e de co-participação. É possível que tal apresentação estabelecesse uma certa "hierarquia" no processo de construção da identidade, na medida em que uma relação afetiva com a história local, construída através da experiência singular da cor, da luz, do povo, enfim, da atmosfera de uma região, era oferecida como "pano de fundo" para os nobres sentimentos patrióticos, de ordem moral, guiados, portanto, pela razão. Essa hierarquia não estava, contudo, explicitada na decoração de 1922, sendo deixada ao próprio observador a tarefa de estabelecer o elo entre as duas dimensões do programa.

Voltando ao projeto inicial de Taunay, diríamos que, de fato, foi essa subdivisão evidenciada no programa que levou à distribuição diferenciada das encomendas. A pintores paulistas deveria caber a execução do segmento do projeto envolvendo a história local, enquanto a história moral, aquela dos "grandes vultos", seria entregue aos grandes artistas da nação, isto é, aos artistas de maior prestígio da academia carioca: aos nossos pintores de história ${ }^{39}$.

Há em tudo isso, porém, um aspecto de grande importância, que nos interessa examinar mais de perto aqui. Buscando subsídios visuais para a realização efetiva da decoração, Taunay retomaria duas vertentes até certo ponto antagônicas dentro da curta tradição pictórica brasileira, lançando mão da linguagem formal desenvolvida por cada uma dessas vertentes no esforço comum para construir uma identidade nacional através da arte. Enquanto, para o corpo do edifício Taunay adotaria o modelo tradicional da pintura histórica, servindo-se, como dissemos, do exemplo de Pedro Américo, para as "salas de iconografia paulista" ele lançaria mão do modelo do grande regionalista Almeida Jr., cujo quadro "A Partida das Monções", pintado em 1897, Taunay traria de volta ao Museu para compor a "sala das monções", onde ele figuraria como peça central ${ }^{40}$. mento mero, sem contudo fazer dela uma cópia servil, o que repugnaria ao meu temperamento e à minha consciência de artista." (Cf. Carta Rodolfo Amoedo a Taunay, Fundo Museu Paulista/Museu Paulista/ USP).Após árduas negociações, Taunay termina entregando a encomenda do quadro a Domenico Failutti, um pintor atuando em São Paulo, que também aceita realizá-lo por um preço bem mais reduzido.

34.A estátua de D. Pedro I foi entregue somente em 1930 , portanto, muito após as comemorações de 22. Através da mediação de João Batista da Costa, Taunay conseguiu trazer um busto de D. Pedro I de Marc Ferrez, pertencente à Academia do Rio de Janeiro, para ocupar o nicho no Sete de Setembro. Em troca deste favor, Taunay acabou encomendando ao artista um pequeno quadro, $\mathrm{e}$ mais tarde um grande painel para a escadaria.

35. Nicolla Rollo (1889 1970). Escultor italiano, foi aluno do escultor Adolfo Adinolfi no Liceu de Artes Ofícios de São Paulo, onde em seguida tornou-se professor:Trabalhou principalmente para uma clientela paulista.

36.Amadeo Zani (1869 — 1944). Escultor nascido em Rovigo, Itália, foi discípulo de Rodolfo Bernardelli e professor do Liceu de Artes e Ofícios de São Paulo. Trabalhou eminentemente para uma clientela paulista, tendo realizado importantes monumentos funerários na cidade.

37. A idéia inicial era dar toda a encomenda de estátuas a Brizzolara (Cf.carta de Brizzolara com orcamento, 5/5/1920, Fundo Museu Paulista, Museu Paulista/USP), porém ele acabou alterando o projeto, dando a artistas paulistas a encomenda dos 6 bandeirantes da escadaria. Os bandeirantes 
representados são os seguintes: de Zani: Pascoal Moreira Cabral e Bartolomeu Bueno da Silva (O Anhangüera); de Rollo, Francisco Dias Velho e Borba Gato; de Emelem, Manuel Prêto e Francisco de Bento Peixoto. É importante notar, para fins do presente artigo, que os nomes próprios desses bandeirantes desapareceram na referência que Taunay fez a eles em seu Guia da Secção Histórica, em 1937.Também os dois bandeirantes de Brizzolara passaram a representar "dois grandes ciclos bandeirantes: o da caça ao índio e devassa do sertão [...] e o do ouro e pedras preciosas". Cf. Taunay, Guia da Secção Histórica, op. cit., p. 57

38. Esse painel nunca chegou a ser instalado, tendo sido substituído pelo dos bandeirantes criadores de gado, encomendado em 1923 a João Batista da Costa.O quadro deveria figurar um bandeirante "alto, musculoso,bronzeado de sol,de grande barba,no gênero do Domingos Jorge Velho [...]." Cf. Carta de Taunay a João Batista da Costa, 18/7/1023, Fundo Museu Paulista/Museu Paulista/USP.

39. Certamente a escolha de artistas paulistas para a realização das encomendas para as "salas"baseava-se na crença de que a experiência da paisagem paulista era fundamental para uma boa caracterização do ambiente na obra.

40.O quadro deAlmeida Jr. havia deixado o Museu e encontrava-se na Pinacoteca do Estado, na época em queTaunay iniciou seu projeto de decoração. Com muito empenho,Taunay recuperou o quadro (que hoje ainda se encontra no Museu Paulista) para a passagem das celebrações da Independência em 1922.

41. Carta de Rodolfo Amoedo a Taunay, 12/2/1922, Fundo Museu Paulista, Museu Paulista/USP
Modelo Histórico

Em 1922, em um momento avançado da implementação da primeira fase do projeto decorativo para o Museu, Rodolfo Amoedo escreveu as seguintes linhas para Taunay:

[...] você deseja ver algumas estampas de decoração de palácios da Renascença, para defender o nosso ponto de vista. Fala-me aí também da obra de H. Mayeux — La Composition Decorative - que em tempos lhe emprestei. De pronto e somente de memória junto aqui um cartão em que vão anotadas várias obras que poderá com proveito consultar e que devem existir aí, senão em livrarias, pelo menos na biblioteca do Liceu de São Paulo. ${ }^{41}$

Desde o primeiro momento em que Taunay começou a se ocupar da decoração do Museu Paulista, tal projeto possuía um enquadre bem estabelecido, pois ela não era uma decoração ex-nihilo, mas propunha-se, antes, a completar o projeto do arquiteto Tommaso Bezzi para o edifício ${ }^{42}$. Desta forma, ao buscar modelos para seu trabalho, Taunay apoiou-se largamente em uma tradição clássica de ciclos decorativos que, iniciando-se no Renascimento, ainda se mantinha viva no final do século XIX. A mais destacada realização oitocentista situada no final de uma longa tradição de ciclos decorativos foi, sem dúvida, a Galerie Historique de Versailles ${ }^{43}$, que se tornou rapidamente o modelo para obras do mesmo gênero em todo o mundo. Desde os tempos de Luiz XIV, Versailles havia se tornado, para a França e para o mundo, o paradigma de monumento de culto à Nação, e mesmo na longínqua São Paulo as associações entre o "Palácio do lpiranga" e o Complexo de Versailles eram recorrentes. Assim, podemos ler em um artigo comentando a decoração de Taunay em setembro de 1922:

○ salão de honra é bela sala ornada com o conhecido quadro de Pedro Américo, a Proclamação da Independência, o qual produz boa impressão aos visitantes. A tela é completada por alguns retratos de D. Pedro I à paisana, D. Pedro II, de José Bonifácio. Que esplêndido palácio de evocação poderia ser o Ypiranga, espécie de Versailles paulista. Iniciativa, gosto, amor à história e o monumento do Ypiranga será sempre grande página do passado a fortalecer os contemporâneos, a mostrar-thes um Brasil que se construiu com muita honra, com muito esforço, com muita rapidez. ${ }^{44}$

Em seu livro sobre a Galerie Historique de Versailles, Thomas Gaehtgens aponta justamente para o caráter político didático da concepção de Jussieu, primeiro idealizador do projeto, mais de dez anos antes dele ser plenamente realizado por Nepveu durante o reinado de Lovis-Phillippe. Tal concepção foi profundamente inspirada pelas teorias pedagógicas do Abade Aloisius E.C. Gautier (1745-1818), ao qual ele dedicou em 1833 o seu livro Guide des parents et des maîtres qui enseignent d'après les méthodes de l'àbbé Gautier ${ }^{45}$. Jussieu entregou seu projeto de construção de uma galeria, que fosse ao mesmo tempo representativa da arte francesa e útil para fins pedagógicos, em 1816 . Sua proposta era a de construir uma galeria com cinqüenta pinturas históricas, que permitisse "um estudo de História ao mesmo tempo útil e agradável"46, opondo-se abertamente às idéias de autonomia da arte, presentes em muitas das teorias estéticas já desde o século XVIII47. Essas galeria deveria ser uma aula de patriotismo, mesmo para os mais leigos de seus visitantes. Jussier criou um grande programa histórico que foi ainda mais aprimorado durante os projetos para a realização das galerias históricas na asa sul do palácio de Versailles. 
Tal associação entre prazer estético e utilidade, que fundamentava a decoração do palácio francês, assim como sua explícita organização ideológica, parece aproximar-se bastante das intenções do próprio Taunay, ao idealizar sua - comparativamente pequena - versão da história brasileira no "Palácio da Independência". Como historiador que era, não pode haver dúvidas de que a relação entre história e estética lhe parecia profundamente atraente. Porém, ao conceber seu ciclo decorativo para o corpo principal do edifício do lpiranga, Taunay não se apoiaria unicamente em modelos europeus. Ele se voltaria, ao mesmo tempo, para a própria cena artística brasileira, buscando referências importantes na produção local que the permitissem dar uma forma visual ao seu projeto de historiador.

Desde a chegada da Missão Francesa ao Rio de Janeiro, em 1816, podemos acompanhar os renovados esforços dos artistas ligados à Academia de Belas Artes para instaurar uma tradição de pintura histórica no Brasil. No ano de 1855, com a posse de Manuel Araujo Porto-Alegre como diretor da Academia - e recebendo impulso algumas décadas mais tarde com o evento da Guerra do Paraguai - estabeleceu-se um programa sistemático de formação de pintores históricos, destinados, em primeiro lugar, a criar o imaginário heróico da nação. ${ }^{48}$ Pode-se ler na Ata da Sessão pública da Academia Imperial de 5 de maio de 1864: "Em nossa história curta abundam já os feitos gloriosos que excitam os talentos e inspiram o gênio [...] preparai-vos para transmitir aos vindouros essa memória gloriosa e vossas obras de arte serão ao mesmo tempo grandes obras de patriotismo [... $]^{\prime \prime}$.

Os dois pintores históricos mais importantes, formados dentro dessas novas diretrizes seriam Victor Meirelles ${ }^{49}$ e Pedro Américo, ambos do circulo de relacionamentos próximos de Porto-Alegre. Sendo que o grande quadro histórico de Pedro Américo, Independência ou Morte! (FIGURA 6) já se encontrava no Palácio do lpiranga desde 1895, fazendo parte portanto dos elementos a priori considerados por Taunay como pontos de partida de sua decoração, a utilização dessa tradição no restante dos elementos decorativos era quase natural ${ }^{50}$. De fato, todo o salão nobre e a sanca, assim como a parte superior das paredes laterais ao longo da escadaria, funcionam como uma grande introdução à apoteose do "Brado", alternando cenas históricas com os "retratos de grandes homens"

Também os painéis retratando os bandeirantes, assim como as seis estátuas ao longo da escadaria e as duas estátuas de mármore de Brizzolara, no hall de entrada do edifício, homenageavam os bandeirantes paulistas, dentro da mesma tradição de pintura histórica, apresentando-os como verdadeiros heróis da história de construção do País ${ }^{5}$. Podemos aqui perceber o desejo de Taunay de integrar personagens paulistas à história da formação do Brasil, ainda que a maneira pela qual essa integração foi ensaiada-, ou seja, através da celebração de grandes vultos bandeirantes — não permitia a Taunay narrar a forma pela qual se dera essa participação ${ }^{52}$.

Entregar as encomendas da decoração do edifício aos artistas da Escola de Belas Artes significava por conseguinte, não só uma forma de projetar São Paulo no seio da vida cultural do País, trazendo para o Museu obras de alta qualidade produzidas por artistas de prestígio, mas também filiar a decoração do corpo central do edifício à tradição específica de pintura histórica praticada por esses artistas, concepção esta que traduzia uma determinada visão de história, bem adequada ao caráter de monumento do edifício, mas que, no entanto, se chocava com as posições teóricas defendidas por Taunay, como historiador.
42.A 28/6/1919, Taunay escreveu ao secretário do Interior: "Bem sabe V.Excia quanto o Museu se acha mal aparelhado para a grande festa de 1922, quanto as suas exposições, a sua ornamentação por acabar inteiramente, discordam da riqueza da sua linha arquitetônica". E em outra carta ao mesmo secretário, lê-se:" [...] No grande saguão deixou o arquiteto lugar para quatro estátuas grandes.A escadaria suntuosa de mármore está por se revestir. Em torno de sua caixa estabeleceu o arquiteto sete pedestais para estátuas encostadas à parede, quatro grandes painéis para pinturas, quatro óculos para retratos. Na sanca sobre a qual se abre a clarabóia iluminadora da escadaria há dezoito grandes painéis para retratos e quatro para motivos decorativos. À escadaria acompanham o suntuoso salão de honra onde se acha o belo quadro de PedroAmérico.Quase tudo está ali por fazer, pois há lugar marcado para quatro grandes composições históricas, dois painéis para retratos.[...]." Em 1/6/1921, por fim, Taunay escreveu para o filho do arquiteto tirando algumas dúvidas a respeito do projeto de seu pai. "Preciso instantaneamente saber se no projeto original do Monumento do Ipiranga executado pelo ilustre pai deV.Excia.a galeria do andar térreo era destinada a ficar em aberto, ou a receber portas envidraçadas. Conta-me que V. Excia. possui todos os desenhos do ilustre arquiteto de quem é filho, relativos ao palácio do Museu Paulista e é o que me leva a recorrer a seu cavalheirismo e gentileza." Cf. Documentos do Fundo Museu Paulista, Museu Paulista/USP.

43. Os primeiros planos para a realização de uma Galerie Historique no palácio de Versailles remontam ao ano de 1816, quando Laurent-Pierre de Jussieu entregou seus planos de construção de uma galeria que contivesse um resumo da história da França em quadros,consti- 
tuindo um verdadeiro curso de história nacional. Esse projeto tornou-se o cerne da nova proposta de Nepveu, apresentada em 1833. Cf. Thomas Gaehtgens, Versailles als Nationaldenkmal, Berlim, 1984.

44.Cf."OYpiranga”,In: $E u$ sei tudo. Rio de Janeiro, set. 1922.

45. Cf. Gaehtgens, op. cit.

46. Id., p. 65

47. Na França vale citar o caso de Diderot.É interessante lembrar ainda que as teorias de Hegel sobre a autonomização da arte, contidas em seus Cursos de Estética, foram escritas entre 1818 e 1829 , sendo praticamente contemporâneas ao planejamento da Galerie Historieque de Versailles

48. Sobre a relação entre a pintura histórica da segunda metade do século XIX e a política imperial, ver: MATTOS, Claudia Valladão de."Independência ou Morte!: O Quadro, a Academia e o Projeto Nacionalista do Imperador." In: OLIVEIRA, Cecilia Helena de Salles; MATTOS, Claudia Valladão de Mattos (Org.). O brado do Ipiranga. São Paulo: Edusp, 1999

49. Victor Meirelles (1832 - 1903).Ao lado de Pedro Américo, foi um dos principais pintores do período do Império. Ingressou em 1847 na Academia Imperial de Belas Artes e em 1852 conquistou o prêmio de viagem à Europa, estudando na França e na Itália. Ao retornar ao Brasil em 1861, foi nomeado professor da Academia, onde permaneceu como professor até 1890 , quando deixou o cargo após a queda do Império.

50. Não devemos nos esquecer que Taunay decorava um monumento à Independência, que por si tendia a situar a decoracão, como dissemos acima, no âmbito de uma arte celebrativa.
Paisagem e História

Em contraste com essa "história dos grandes vultos" — tão adequada ao caráter celebrativo do prédio e traduzida para uma linguagem visual através de sua vinculação à tradição da pintura histórica - Taunay adotou para as "Salas de Iconografia Paulista" um outro modelo histórico. Nelas, não eram mais os grandes feitos políticos que estabeleciam a lógica da produção de significado, mas um processo cumulativo de atividade civilizatória. A construção de uma identidade paulista era mediada ali pela própria história da construção da cidade e do Estado de São Paulo. Não eram mais os grandes feitos que faziam a história, mas propunha-se uma espécie de "história do cotidiano", traduzida visualmente através da idéia de panorama histórico. Um modelo que, de fato, se adequava mais facilmente às concepções teóricas de Taunay.

Seria através da decoração dessas "salas", então, que Taunay encontraria a chave para a tradução de suas teorias sobre a Civilização Brasileira, em imagem. Porém, a sua adoção como modelo geral para toda a decoração do edifício só ocorreu um pouco mais tarde. Inicialmente, quando Taunay começou a fazer as encomendas de vistas panorâmicas para artistas paulistas /a partir de 1917) sua intenção era a de narrar o desenvolvimento regional, apresentando ao visitante - através da organização de constelações históricas que se sucediam nas diferentes salas - uma civilização florescente, com a qual ele poderia se identificar ${ }^{53}$. Sugerimos, desse modo, que foi exatamente através da prática concreta de organização das "salas" que Taunay se familiarizou com uma outra forma visual - com tradição própria dentro da história da arte brasileira - , usando-a posteriormente como o fio condutor para a unificação de toda a complexa decoração. Resta-nos indagar, por isso, sobre essa forma alternativa de discurso que evocava igualmente sentimentos de identidade: o panorama histórico.

Como nos mostra Luciano Migliaccio em sua análise da produção artística brasileira do século XIX ${ }^{54}$, a pintura de paisagem tem uma história bastante singular no Brasil. Diferentemente do que acontecia na Europa, onde a pintura histórica ocupava, nas academias, a posição mais prestigiosa e central dentro da hierarquia dos gêneros 55 , tornando-se o veiculo privilegiado de expressão de sentimentos patrióticos, na academia brasileira foi a paisagem que durante muito tempo canalizou as aspirações em relação à construção de uma identidade nacional. $\bigcirc$ fato de Felix-Emil Taunay ${ }^{56}$, diretor da Academia de Belas Artes por quase duas décadas, ter sido um pintor de paisagem, deu ao gênero um destaque inusitado, quando comparado com seu prestígio dentro do contexto europeu.

Entre os anos de 1845 e 1850, durante sua gestão, Felix-Emil Taunay lutou programaticamente pelo desenvolvimento de uma pintura nacional ligada ao gênero da paisagem. Considerando "a relação entre a natureza primordial e a ação do homem [...] o verdadeiro tema da história nacional"57, Felix-Emil Taunay pretendia fazer deste tema o ponto de partida para a construção de um discurso sobre a nação, sendo seus quadros "Mata Reduzida a Carvão" e "Vista da mãe d'água", ambos no Museu Nacional de Belas Artes, bons exemplos desse esforço 58 . Ele foi também um dos primeiros artistas a desenvolver a pintura de panorama no Brasil, buscando dar a ela uma abordagem histórica. Assim, suas vistas do Rio de Janeiro (MNBA) procuram captar a movimentação da cidade, as características da ocupação da terra, juntamente com o colorido local ${ }^{59}$. 


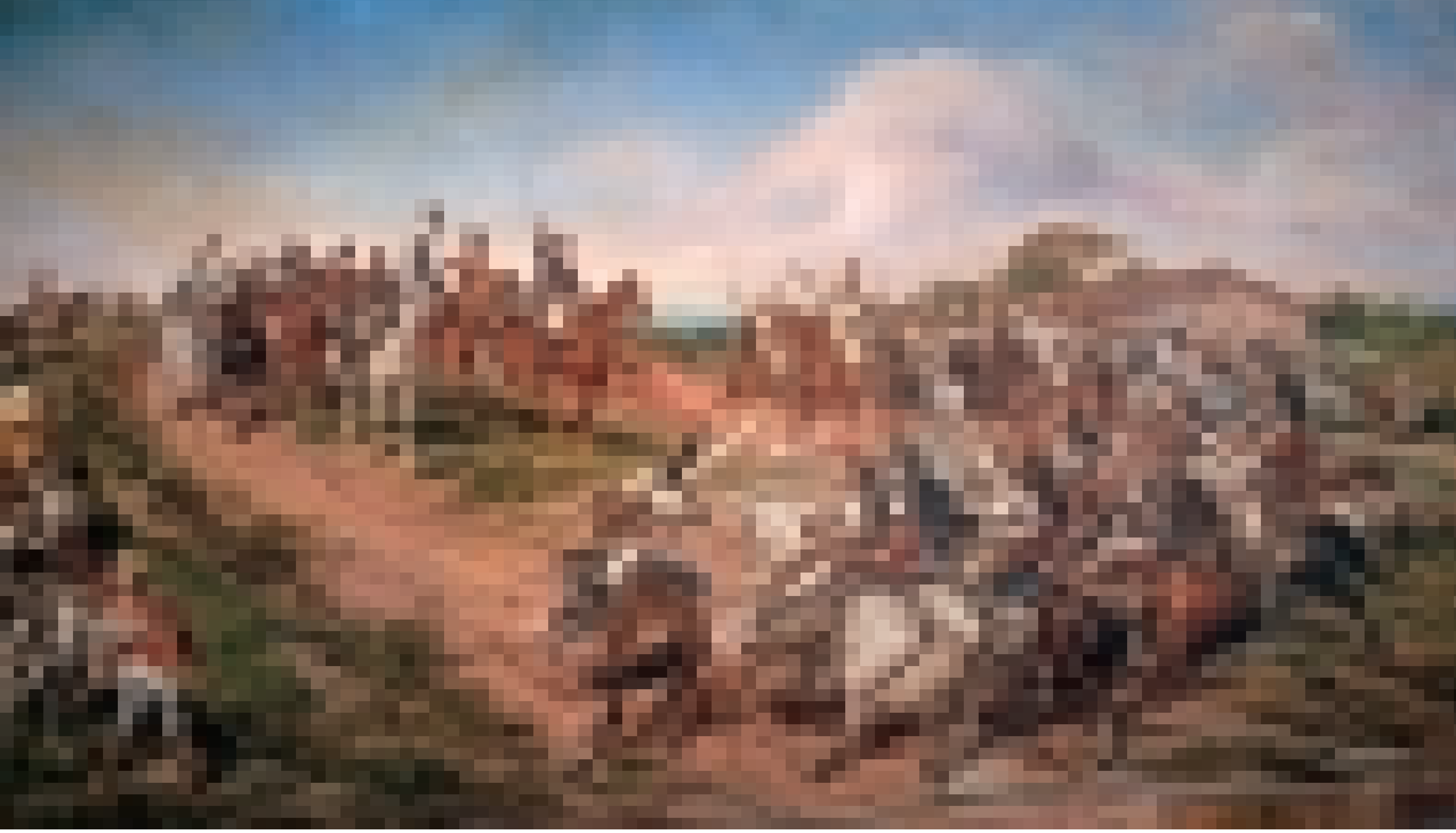


Em 1854, com a posse de Porto-Alegre na Academia e a realização da assim chamada "Reforma Pedreira", a pintura histórica retornou, como já vimos, como o locus privilegiado de celebração do "nacional", ainda que Porto-Alegre valorizasse o projeto de seu antecessor como caminho correto para o desenvolvimento de uma pintura de paisagem tipicamente "brasileira". Porém, no final do século, vemos ressurgir a mesma noção de paisagem histórica, nos panoramas de um dos maiores pintores históricos do País: Victor Meirelles. Seu panorama do Rio de Janeiro, apresentado em Bruxelas e na Exposição Universal de Paris em 188960, retomou o projeto de Felix-Emil Taunay ao mostrar uma cidade pontuada de monumentos e edifícios significativos para a história nacional (destacando, por exemplo o monumento a D.Pedro I de Louis Rochet, hoje na praça Tiradentes) ${ }^{61}$. Em 1899, Victor Meirelles retomaria esse projeto com o Panorama do Descobrimento do Brasil, onde seu próprio quadro histórico de 1863 seria inserido em uma vasta paisagem praiana de Porto Seguro 62

Em um diálogo com as paisagens históricas de Victor Meirelles, o quadro de Almeida Jr., "A Partida das Monções" (1 897) (FIGURA 7), que pertence ao Museu Paulista - e para o qual Affonso Taunay dedicou uma de suas "salas"
51. Cabe aqui um comentário a respeito das obras realizadas por Henrique Bernardelli e Rodolfo Amoedo paraTaunay no contexto do projeto de decoração aqui em questão. Em seu artigo "Bandeirantes na Contramão da História: Um Estudo Iconográfico", Maraliz de Castro Christo demostra de forma convincente que tanto Henrique Bernardelli quanto RodolfoAmoedo,na verdade, não se submeteram integralmente à concepção de Taunay, por discordarem de sua interpretação heróica das figuras dos bandeirantes.Como diz a autora, essa diferença de opinião em relação aTaunay terminou por evidenciar-se nas próprias pinturas, onde os bandeirantes aparecem sob a perspectiva da "natu-

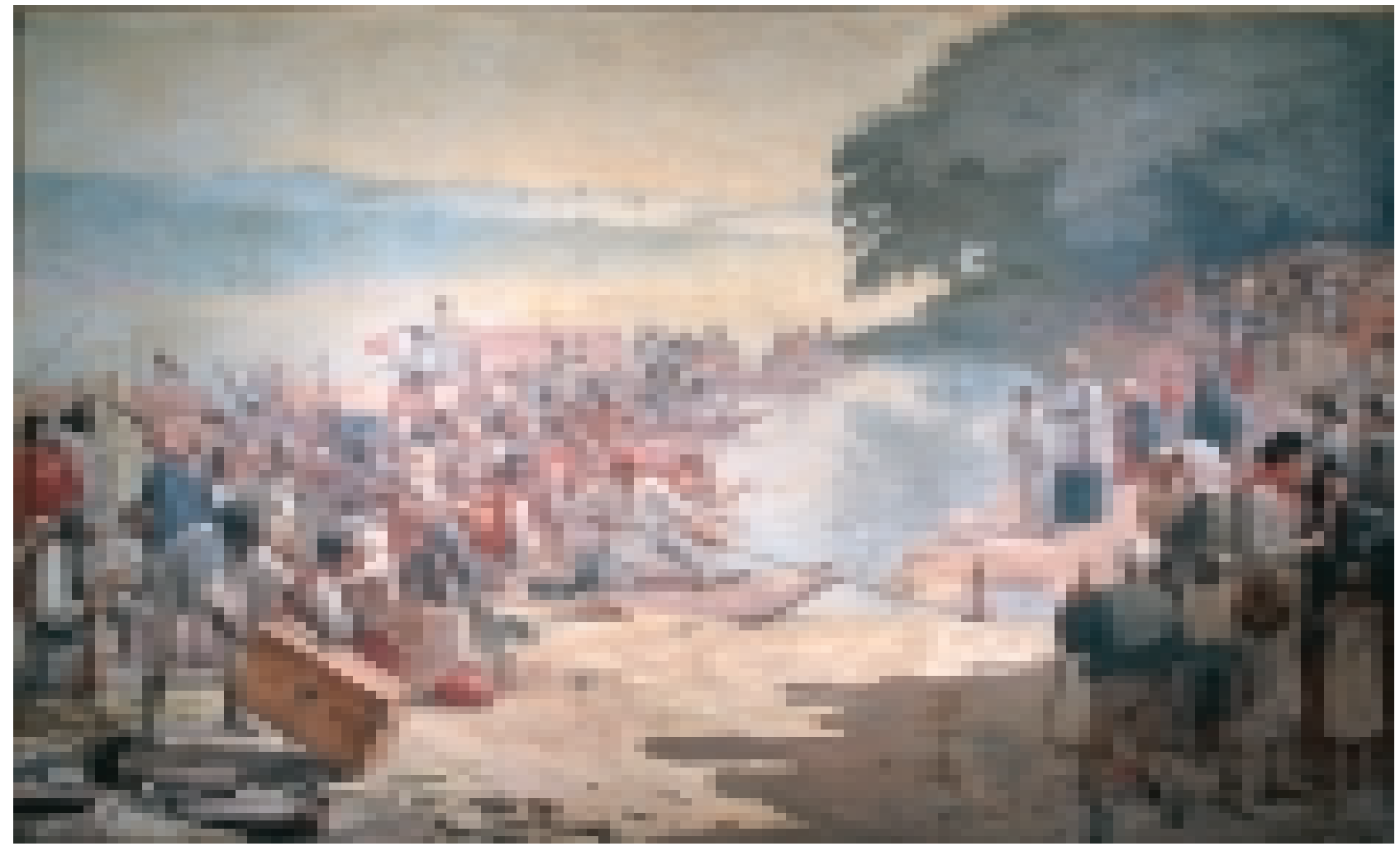

FIGURA 7 - Almeida Júnior. A Partida da Monção, 1897, óleo sobre tela, 390 × 640 cm, São Paulo. Inspirado em desenhos de Hercules Florence. Acervo Museu Paulista da USP. Reprodução de Hélio Nobre. 
reza, incluindo o índio, sobrepondo-se ao homem branco [...] envelhecido e enfermo", em oposição ao índio que mantém seu vigor físico e o caráter moral que adquirira na segunda metade do século XIX com o Romantismo. Cf. CHRISTO, Maraliz. Projeto História, n. 24, p. 307-335, 321, jun. 2002. Aproveito ainda para agradecer à professora Maraliz pela leitura atenta e preciosos comentários ao presente artigo.

52. Aqui tocamos em um ponto fundamental referente à linguagem visual propriamente dita, ou seja, a dependência direta da pintura histórica com relação ao texto escrito, ou melhor dizendo, com relação ao conhecimento prévio da história, pois a pintura de história é, por natureza, sempre erudita.Assim, a tentativa de empregar essa linguagem para contar uma outra versão da formação do Brasil trazia dificuldades adicionais, que Taunay não conseguiu resolver nesse primeiro momento.

53. O bandeirante participava inicialmente da decoração como um exemplo da bravura dos paulistas.

54. Cf. MigLIACCIO, Luciano. O século XIX. In: MOSTRA do redescobrimento Brasil 500 anos artes visuais. São Paulo, Associação Brasil 500 Anos Artes Visuais, 2000. Catálogo de exposição.

55. Devemos notar, no entanto, que o gênero da pintura de paisagem ganhou uma nova dimensão fora das academias, a partir do século XVIII, contribuindo para a desconstrução da hierarquias dos gêneros que reinava nas mesmas e que situava a pintura histórica no ponto mais alto de sua escala. Sobre a questão da transformação do quadro das artes durante o século XVIII, ver:BUSCH,Werner. Das Sentimentalische Bild. Die Krise der Kunst im 18. Jabrbundert und
- deu continuidade ao antigo projeto nacional presente na pintura de paisagem brasileira, sendo ao mesmo tempo o elo mais significativo entre essa tradição e o programa de Affonso Taunay para as "Salas de Iconografia Paulista"63. Mesmo não sendo um panorama, como as pinturas de Meirelles, "A Partida das Monções" aproxima-se deste gênero pelas dimensões excepcionais, que convidam 0 observador a "imergir" na cena histórica representada. E mesmo muito provável que o quadro de Almeida Jr. tenha fornecido a chave para essa parte da decoração, da mesma forma que o modelo do quadro de Pedro Américo o inspirara no desenvolvimento do programa para o corpo central do edifício.

De fato, as "Salas de Iconografia Paulista" alinham-se em sua concepção à visão oferecida por Almeida Jr., visando a reconstruir a paisagem histórica na tradição das pinturas de Felix-Emil e Meirelles. São Paulo é vista, ao longo do percurso das várias salas, sob o viés de seu momento fundador: o bandeirantismo, que, ao mesmo tempo, estabelece a importância e o significado de sua história subsequente. Essa história é apresentada nas duas primeiras salas da ala oeste com a "Sala das Monções" (com o quadro de Almeida Jr.) e a "Sala da Cartografia Colonial e Documentos Antigos" (com uma grande "Carta Geral das Bandeiras Paulistas") (FIGURA 5), de autoria de Taunay, e o quadro "Desembarque de Martim Afonso em São Vicente em 1532", encomendado a Benedito Calixto ${ }^{64}$. Em seguida, sob as bases desse passado glorioso, Taunay apresentou uma série de salas lao todo 4), com vistas da cidade, em determinados momentos de sua história, encomendadas a artistas que as pintaram a partir de documentos fotográficos, mas reorganizando-as em composições que buscam ressaltar edifícios importantes e "limpar" a cidade do aspecto "não-civilizado" que ela possuía ${ }^{65}$. O resultado é uma seqüência de "panoramas" (cada sala igualando-se a um grande panorama), que visava a transportar o visitante, de instância em instância, através do tempo, traçando uma ponte entre passado e presente e, com isto, construindo uma identidade paulista. Fundamental nessa concepção era a idéia de passagem — passagem de um quadro a outro, passagem de sala a sala - que servia também como metáfora da "passagem" do tempo. Havia na disposição das "salas", em contraste com a organização celebrativa e pontual do corpo central do edifício, a incorporação de um percurso, que era ao mesmo tempo o percurso pelas salas e pela história.

Assim, se tínhamos, na virada do século, duas vias concorrentes que buscavam igualmente a construção de uma identidade nacional através da arte por um lado, a tradicional Pintura Histórica celebrativa, que viveu seu grande momento com os quadros históricos de Pedro Américo e Victor Meirelles e, por outro, a Paisagem Histórica, que propunha construir uma identidade para a nação através de um discurso sobre a ocupação do território - Taunay faria uso das duas, ao menos em uma primeira etapa de implantação de seu projeto decorativo. Mas não demorou muito para a segunda forma visual comprovar-se mais adequada às suas próprias convicções de historiador. Assim, pouco após a inauguração da decoração em 1922, Taunay partiria para uma segunda fase de trabalho, durante a qual ele buscaria, na medida do possível, adaptar todo o programa decorativo a esse segundo modelo formal.

\section{Contando uma única história}

Entre 1922 e 1937, Taunay acrescentou uma série de elementos à decoração do corpo do edifício, que reorientaram em grande medida o trabalho 
anterior e demostraram com que empenho Taunay buscou obliterar o caráter celebrativo que caracterizava a decoração do corpo central, a fim de unificar toda a decoração do edifício sob a égide de uma concepção evolutiva de história . Se em sua historiografia, o elo entre o regionalismo paulista e sentimentos patrióticos fora dado pela história da expansão do bandeirantismo, essa idéia de expansão, de processo contínuo e de passagem passaria a guiar Taunay nesse segundo momento. Sucintamente, Taunay transportou o modelo do panorama histórico ${ }^{66}$, aplicado anteriormente às salas, para todo o edifício, transformando-o em uma grande narrativa sobre a construção do Brasilb7.

A fim de contar essa história, Taunay introduziu os quatro painéis de Wasth Rodrigues no hall de entrada: "D. João III", "João Ramalho", "Martim Afonso de Souza" e "Tibiriçá", que falam do sucesso da implantação da Capitania de São Vicente, instituindo-a como o núcleo originário da formação da nação. A partir desse ponto a decoração se abre para duas vertentes: no mesmo andar, conta-se através das salas o desdobramento da história local, enquanto, no corpo central, ela desenvolve a narrativa simultânea e paralela da construção da nação brasileira. A idéia de evolução e percurso é expressa aqui através de dois artifícios: por um lado, Taunay acrescentou uma série de vasos com águas dos principais rios que delineiam o território nacionalo8, incluindo também em cada pedestal de estátua bandeirante o nome de um Estado e sua data de separação da província de São Paulo69; por outro, ele transformou os bandeirantes dos painéis, concebidos originariamente como homenagens a personalidades individuais, em figuras-"símbolo" de ciclos econômicos que marcaram a história do Brasil, acrescentando sobre cada uma delas uma legenda ${ }^{70}$. Por último, essa narrativa desembocou, por assim dizer, no episódio da Independência, transformado-o em epílogo de todo o processo ${ }^{71}$. Assim, toda a narrativa anterior, fez do ato de Independência uma conseqüência da história e não da coragem de um homem, desmobilizando o caráter de exceção, inerente ao discurso da pintura histórica.

Se em termos gerais, a nova organização que Taunay deu à decoração apóia-se no modelo da paisagem histórica, a solução concreta dos problemas de composição (do todo da decoração) impostos por essa nova forma, foi encontrada, a nosso ver, durante o próprio processo de organização das "salas", ainda antes de 1922, mais especificamente, durante suas pesquisas para realizar uma "Grande Carta Geral das Bandeiras Paulistas" - para a sala da "Cartografia Colonial". Esse mapa, que representava justamente os rios que ajudaram no avanço dos bandeirantes para dentro do território, assim como os focos de colonização no interior do País, forneceu a "metáfora" ideal que permitiria falar da formação do Brasil, projetando São Paulo como o principal responsável pela grandeza do território e pelo surgimento da Nação.

Finalmente Taunay havia inventado um modelo visual que correspondia mais perfeitamente à sua própria visão de historiador. Em 1951, ele publicaria uma nova versão de sua História das Bandeiras Paulistas, resumindo-a em dois volumes, e nessa edição, acompanhando passo a passo o texto, encontramos reproduções de todos os detalhes da decoração do Museu Paulista, confirmando a traduzibilidade alcançada por Taunay entre a versão escrita e a versão visual de sua história. die Geburt der Moderne. Munique: Beck, 1993.

56. Não consideramos uma coincidência o fato de Affonso Taunay ser neto de Felix-EmilTaunay. 57. Cf. Migliaccio, op. cit. 58. id.

59. Id. Sobre panoramas, ver ainda CARVALHO, Anna Maria F. M. "Panorama no Brasil." In: $O B R A$ SIL redescoberto. Rio de Janeiro, set./nov. 1999. p. 105-123.

60. Cf. BARBURY, Heloisa. "O Brasil vai a Paris em 1889: um lugar na Exposição Universal." Anais do Museu Paulista: História e Cultura Material, São Paulo, v. 4, p. 211-261, 1996.

61.Do panorama,hoje perdido, restam apenas seis estudos que se encontram no MNBA no Rio de Janeiro.

62. Refiro-me aqui ao quadro "A Primeira Missa no Brasil" (MNBA/RJ). É interessante notar que a sua insercão em um cenário panorâmico transforma radicalmente o sentido da obra. Enquanto a "Primeira Missa", com suas referências européias - Jorge Coli aponta para o quadro "Premiére Messe en Kabilie", de Horace Vernet, como sua principal fonte de inspiração - dá continuidade à tradição celebrativa da pintura histórica, o panorama reorienta a significação na medida em que apresenta a cena como um pequeno núcleo de civilização em meio a uma natureza virgem, ressaltando assim a questão da ocupação do território e da inauguração de um processo civilizatório de ocupação. Interessante no nosso contexto é ainda o fato desse panorama ter sido criado para as comemorações dos 400 anos de descobrimento do Brasil em1900. Sobre a "Primeira Missa", ver: COLI,Jorge."Primeira Missa.A Invenção da Descoberta."In:A DESCOBERTA do Homem e do Mundo. São Paulo: Minl- 
Funarte/Companhia das Letras, 1998. p. 107-121.

63. Tendo em vista que Felix-EmilTaunay era o avô do nosso Affonso Taunay, não é surpreendente sua vinculação com o projeto do primeiro. Taunay mantinha grande interesse pela produção de seus antepassados, tendo escrito um livro sobre seu famoso bisavô Nicolau Antoine e outro sobre a Missão Francesa, além de artigos sobre Aimé (irmão de Felix-Emil e companheiro de Hercules Florence na expedição Langsdorf, que morreu afogado durante a mesma).

64. Benedito Calixto (1853 - 1927). Pintor de paisagem atuante em São Paulo, foi professor do Liceu de Artes e Oficios.

65. Sobre a relação entre os quadros e os documentos fotográficos usados por Taunay, cf. Solange Lima e Vânia Carvalho, op. cit.

66. É fundamental ressaltar novamente aqui a idéia de "passagem" da paisagem natural para a da civilização, presente no programa de Felix-Emil, retomado depois por Meirelles em seu "Panorama com a Primeira Missa no Brasil"e porAlmeida Jr.em sua"Partida das Monções".

67.A orientação vertical da decoração (que se inicia no térreo e se expande pela escadaria, atingindo então o primeiro andar) apóia essa idéia de "construção" paulatina da nação.

68. A idéia de falar da expansão bandeirante através da metáfora do rio já havia ocorrido a Taunay em 1920. Em um discurso proferido em Porto Feliz e publicado sob o título A Glória das Moncões (São Paulo: Editora "O Livro", 1920),Taunay citou um episódio da história antiga, que descreve a presença de tais vasos no palácio de Persépolis,posteriormente destruído por Alexandre, para em seguida dizer que uma ânfora com água do

\section{REFERÊNCIAS}

BARBUY, Heloisa. “O Brasil vai a Paris em 1889: um lugar na Exposição Universal.” Anais do Museu Paulista: História e Cultura Material, São Paulo, v. 4, 1996.

BREFE,Ana Claudia Fonseca. Um Lugar de Memória para a Nação. O Museu Paulista reinventado por Affonso d'Escagnolle Taunay (1917-1945). 1999.304 f.Tese (Doutorado) - Departamento de História/Unicamp, Campinas, 1999.

BUSCH, Werner. Das Sentimentalische Bild. Die Krise der Kunst im 18. Jabrhundert und die Geburt der Moderne. Munique: Beck, 1993.

CARVALHO,Anna Maria F. M."Panorama no Brasil." In: O BRASIL redescoberto. Rio de Janeiro, set/ nov. 1999. Catálogo de exposição.

CHRISTO, Maraliz de Castro. "Bandeirantes na Contramão da História: Um Estudo Iconográfico." Projeto História, n. 24, p. 307-335, jun. 2002.

COLI,Jorge."Primeira Missa.A Invenção da Descoberta." In:A DESCOBERTA do homem e do mundo. São Paulo: Funarte/Companhia das Letras, 1998.

ELIAS, Maria José. "Museu Paulista, memória e história”. 1996. 473 f.Tese (Doutorado) - Faculdade de Filosofia, Letras e Ciências Humanas, Universidade de São Paulo, São Paulo, 1996.

GAEHTGENS, Thomas. Versailles als Nationaldenkmal. Berlim: [s.n.], 1984.

LIMA, Luiz da Costa.Terra Ignota.A construção de Os sertões. Rio de Janeiro: Civilização Brasileira, 1997.

LIMA, Solange; CARVALHO,Vânia."São Paulo Antigo, uma encomenda da modernidade:as fotografias de Militão nas pinturas do Museu Paulista." Anais do Museu Paulista, Nova Série, n. 1, p. 147-178, 1993.

MAKINO, Miyoko.“A OrnamentaçãoAlegórica.”In:WITTER,José Sebastião;BARBUY,Heloisa (Org.) Um monumento no Ipiranga: história de um edifício centenário e sua recuperação. São Paulo: FIESP/CIESP/SESI/SENAI/IRS, 1997.

MATTOS, Claudia Valladão de. "Independência ou Morte! O Quadro, a Academia e o Projeto Nacionalista do Imperador”. In: OLIVEIRA, Cecília Helena de Salles Oliveira;MATTOS, Claudia Valladão de (Org.). O brado do Ipiranga. São Paulo: Edusp, 1999.

MATTOS, Odilon Nogueira de.Affonso de Taunay:historiador de São Paulo e do Brasil. São Paulo: Coleção Museu Paulista, 1977 (Série Ensaios, v. 1).

MENESES, Ulpiano T. Bezera de. "O Salão Nobre do Museu Paulista e o Teatro da História." In: ÀS MARGENS do Ipiranga: 1800-1990. São Paulo:Bradesco/Museu Paulista, 1990. Catálogo de exposição. 
MIGLIACCIO, Luciano. “O Século XIX.” In: MOSTRA do redescobrimento Brasil 500 anos artes visuais. São Paulo:Associação Brasil 500 Anos Artes Visuais, 2000. Catálogo de exposição.

OLIVEIRA, Cecília Helena de Salles."O Museu Paulista e o Imaginário da Independência.” In: MUSEU Paulista: Novas Leituras. São Paulo: Museu Paulista/USP, 1995. p. 5-9.

SCHWARCZ, Lilia. O espetáculo das raças - cientistas, instituições e questões raciais no Brasil: 1870-1930. São Paulo: Companhia das Letras, 1993.

SEVCENKO, Nicolau. "Museu Paulista: História, Mito e Crítica." In: Às MARGENS do Ipiranga: 18001990. São Paulo: Bradesco/Museu Paulista, 1990. Catálogo de exposição.

TAUNAY,Affonso E. Guia da secção bistórica do Museu Paulista. São Paulo: Imprensa Oficial do Estado de São Paulo, 1937.

.J.Capistrano de Abreu in Memoriam." Anais do Museu Paulista, t. 3, p. XVII, 1927.

.A glória das monções. São Paulo: Editora “O Livro”, 1920.

Artigo reapresentado em 3/2003. Aprovado em 9/2003.
Tietê caberia em um monumento às bandeiras:

"Senhores! Referem os historiadores das primeiras eras que no admirável palácio de Persépolis, destruído graças a um momento de desvaire do conquistador macedônio, havia entre mil maravilhas uma sala cuja majestade nenhuma outra sobrepujava. E, no entanto, nada de extraordinariamente se notava na sua decoração [...]. Não passava de enorme cômodo nu, vazio, onde em cada ângulo se notava apenas uma ânfora de mármore cheia de água.[...]Assim, senhores, quando a gratidão brasileira se impuser, como saldamento imperioso de uma dívida enorme, a necessidade de ereção de um monumento destinado a rememorar os fatos daqueles que alargaram o Brasil pela América do Sul adentro - e no dia em que um monumento nacional como o que se vai erigir aos homens da nossa Independência se erguer a estes filhos de São Paulo [...] ficaremos certos de que a tal monumento não pode faltar o lugar para a ânfora d'água do rio das bandeiras paulistas! [...], p. 39-40. É evidente, no entanto, que ele não incluía os vasos em seu projeto inicial para o Ipiranga, e que essa idéia só lhe ocorreu mais tarde, após 1922, como vimos.

69.Todos os detalhes acrescentados à decoração entre 1922 e 1937 concorrem para explicitar este programa, assim também os 9 brasões das cidades mais antigas de São Paulo, colocados ao longo de toda a escadaria,reforçam a origem da nação no território paulista.

70. Os ciclos são os seguintes:"Ciclo da Caça ao Índio" (Henrique Bernardelli),"Ciclo do Gado" (João Batista da Costa), "Ciclo da Mineração" (Rodolfo Amoedo), "A posse da Amazônia" (Fernandes Machado).

71. Toda a organização anterior do discurso desmobiliza o caráter de exceção do discurso inerente à pintura histórica. 
This article deals with some of the main aspects concerning the interrelation among the artistic praxis and the work of art circulation and mediation circles, during the period known as Belle Époque. The popping up of specific phenomena related to this field was stimulated by this scenario of deep changes, in the most different levels, which had been established in the capital city of São Paulo as a consequence of the Republic proclamation, the coffee fieldwork expansion and the industry growth. The wide circle that was then created around art, here exemplified by the exhibitions and by the exhibition spaces allowed us to learn the main constitutive elements of São Paulo's artistic field just as it ecloded.

KEYWORDS: São Paulo.Artistic Field. Material Culture.Art Market

Anais do Museu Paulista. São Paulo. N. Sér. v. 6/7.p. 83-119 (1998-1999). Editado em 2003.

Da Palavra à Imagem: sobre o programa decorativo de Affonso Taunay para o Museu Paulista

\section{Claudia Valladão de Mattos}

presente artigo analisa a decoração interna do Museu Paulista, criada e implementada por Affonso d'Escagnolle Taunay durante sua gestão como diretor daquela instituição, procurando compreender as estratégias utilizadas por ele para traduzir suas convicções teóricas em uma linguagem visual convincente. A autora analisa ainda os vínculos do projeto proposto por Taunay com a vasta tradição de ciclos decorativos europeus e, mais especificamente, com os projetos de construção de uma identidade nacional através da pintura, defendida por alguns artistas ligados à Academia de Belas Artes durante o século XIX.

PALAVRAS-CHAVE: Museu Paulista. Ciclo decorativo.Taunay. História da arte.

Anais do Museu Paulista. São Paulo. N. Sér. v. 6/7. p. 123-145 (1998-1999). Editado em 2003.

From the Word to the Image: about Affonso Taunay's decorative program for the Museu Paulista

\section{Claudia Valladão de Mattos}

The present paper studies the internal decoration of the Museu Paulista, created and implemented by Affonso D'Escagnolle Taunay during his term as a director of that institution, trying to understand the strategies he used to translate his theoretical convictions into a convincing visual language. The author also analyses the relations of Taunay's proposed decorative project with the vast tradition of European decorative cycles and, more specifically, with the projects of the construction of a national identity through painting, which was defended by some artists who had a certain relation with the Fine-Arts Academy during the 19th century.

KEYWORDS: Museu Paulista. Decorative cycle.Taunay. History of Art.

Anais do Museu Paulista. São Paulo. N. Sér. v. 6/7.p. 123-145 (1998-1999). Editado em 2003.

Reflexões sobre a cor na conservação/restauração

Teresa Cristina Toledo de Paula / Museu Paulista da USP

Este texto apresenta algumas possibilidades de pesquisa do tema Cor dentro das áreas de conservação/restauração de bens móveis. São apresentados alguns exemplos do tema Cor relacionado aos tecidos e às artes contemporâneas. Questões específicas à Arquitetura não são abordadas.

PALAVRAS-CHAVE: Conservação. Restauração. Cor.Tecidos no Brasil.

Anais do Museu Paulista. São Paulo. N. Sér. v. 6/7.p. 149-159 (1998-1999). Editado em 2003.

Reflection about colour in conservation/restoration

Teresa Cristina Toledo de Paula / Museu Paulista da USP

This paper presents some research possibilities related to Colour as a main issue. Some examples of the study of colour in textiles and modern art are given. Architecture related issues are not covered.

KEYWORDS: Conservation. Restoration. Colour.Textiles in Brazil.

Anais do Museu Paulista. São Paulo. N. Sér. v. 6/7. p. 149-159 (1998-1999). Editado em 2003. 